\title{
EL DESCONOCIMIENTO DE LOS PODERES DE CONTROL POLÍTICO DEL ÓRGANO LEGISLATIVO SOBRE EL GOBIERNO Y LA ADMINISTRACIÓN PÚBLICA POR PARTE DEL JUEZ CONSTITUCIONAL EN VENEZUELA ${ }^{1}$
}

The constitutional judge's ignorance of the legislative body's powers of political control over government and public administration in Venezuela

\author{
Allan R. Brewer-Carías \\ Profesor emérito de la Universidad Central de Venezuela \\ https://doi.org/10.37346/opusmagna.v16i01.6
}

N. del E. Este es un aporte voluntario del maestro Brewer Carías mismo que no fue sometido a evaluación por parte del Consejo Editor. Agradecemos la generosidad del maestro Brewer Carías por compartir sus opiniones a través del Opus Magna Constitucional. 


\section{SUMARIO}

\section{Introducción}

1. El control político por la asamblea nacional de los decretos de estado de excepción y su desconocimiento judicial

2. Los ataques de la Sala Constitucional contra la Asamblea Nacional cercenándole sus poderes de control político sobre el gobierno y de la administración pública

3. El fin del control político que debe ejercer la Asamblea Nacional: la inconstitucional "restricción" impuesta por el Presidente de la República, respecto de su potestad de aprobar votos de censura contra los ministros 


\section{INTRODUCCIÓN}

La Constitución venezolana de 1999, como todas las constituciones contemporáneas latinoamericanas, está montada sobre un sistema de separación de poderes, como garantía del funcionamiento del Estado de derecho, estableciendo diversos mecanismos de control recíproco entre los mismos.

En ese contexto, conforme al artículo 222 de la Constitución, y específicamente sobre el control que la Asamblea Nacional como órgano de representación popular ejerce sobre el Gobierno y la Administración, la Asamblea Nacional tiene poder suficiente para ejercer dicha "función de control" mediante los siguientes mecanismos: "las interpelaciones, las investigaciones, las preguntas, las autorizaciones y las aprobaciones parlamentarias" que se prevén en la Constitución y en la ley, así como "mediante cualquier otro mecanismo que establezcan las leyes y su reglamento."

En ejercicio del control parlamentario, la misma norma constitucional dispone que la Asamblea podrá declarar la responsabilidad política de los funcionarios públicos y solicitar al Ministerio Público que intente las acciones a que haya lugar para hacer efectiva tal responsabilidad.

La Asamblea, además, conforme se indica en el artículo 223 de la misma Constitución, puede realizar las investigaciones que juzgue convenientes en las materias de su competencia, de conformidad con el reglamento interior y de debates, estando todos los funcionarios públicos obligados, bajo las sanciones que establezcan las leyes, a comparecer ante las Comisiones de la misma y a suministrarles las informaciones y documentos que requieran para el cumplimiento de sus funciones.

Esas potestades de control, como a partir de diciembre de 2016 la Asamblea Nacional en Venezuela pasó a estar controlada por la posición política al régimen autoritario, fueron sucesivamente desmanteladas por el Tribunal Supremo de Justicia, en connivencia con el Poder Ejecutivo, en particular por su Sala Constitucional que ejerce la Jurisdicción Constitucional en el país, 
lesionándose gravemente el principio de la separación de poderes y el mutuo control por arte de los órganos del Estado.

Estas páginas, escritas para la obra homenaje a mi amigo de hace tantos años, el profesor Jorge Mario García la Guardia, quien tan bien conoce el rol del Juez Constitucional en un Estado de derecho, es la crónica constitucional de la conducta de un Jue Constitucional, que lejos de haber sido el garante de la Constitución y su supremacía, se convirtió en el más vil instrumento para su violación impune, cercenándole a la Asamblea nacional en Venezuela sus poderes constitucionales de control político sobre el Gobierno y la Administración Pública. 


\section{El control político por la asamblea nacional de los decretos de estado de excepción y su desconocimiento judicial}

\subsection{El incongruente y tardío reconocimiento ejecutivo de la emergencia económica}

El día 15 de enero de 2016, al presentar su Mensaje anual ante la Asamblea Nacional, quien ejercía la Presidencia de la República de Venezuela, Nicolás Maduro, consignó, junto con el mismo, el texto del Decreto No 2.184 de fecha 14 de enero de 2016, ${ }^{2}$ mediante el cual había declarado el estado de emergencia económica en todo el territorio nacional durante un lapso de 60 días, motivado, según se lee en los Considerandos, no en las consecuencias desastrosas de las políticas económicas erradas que ha venido desarrollando el Estado, destruyendo tanto la producción y economía nacional como la calidad de vida de la población, sino en supuestos factores externos al gobierno e incluso al país, entre los cuales estaban:

(i) que sectores nacionales e internacionales habrían iniciado acciones tendientes a "desestabilizar la economía del país;"

(ii) que en el "marco de la guerra económica" iniciada contra el país, se ha dificultado el acceso a bienes y servicios esenciales;

(iii) que "ante la ofensiva económica y la disminución del ingreso petrolero," se requiere adoptar medidas urgentes para garantizar la sostenibilidad de la economía, Y

(iv) que dichas medidas son de "gran magnitud e impacto en la economía nacional."

La crisis económica del país, que definitivamente no se debía a factores externos al Estado, pues era producto de su error e ineficiencia, por supuesto, no se resolvía con decretos, y menos con decretos como el dictado el 14 de enero de 2016, sino con un cambio en la política económica del gobierno que al menos (i) restableciera la producción nacional, en un marco de libertad económica, restituyendo empresas y factores de producción confiscados y expropiados a sus dueños, (ii) desmantelase el enorme aparato burocrático estatal que ha

$2 \quad$ Véase en Gaceta Oficial № 6.214 Extra. de 14 de enero de 2016 
gerenciado la economía nacional, con los más altos índices de ineficiencia de la historia del sector público; y (iii) desregulase la economía, permitiendo al sector privado desarrollar las iniciativas necesarias en materia de producción y empleo, con acceso a divisas en un marco real de valor de la moneda.

Pero no. En lugar de atacar el problema económico, el decreto de emergencia económica de enero de 2016, no fue más que el reconocimiento del fracaso del gobierno en materia económica, pero sin proponer solución alguna para resolver la crisis, y más bien con propuestas para agravarla, pero que en ningún caso requerían de un decreto de emergencia para ser dictado conforme a los artículos 337 y siguientes de la Constitución, pues todo lo que en el decreto se enunció con vaguedad lo podía realizar el Gobierno con el arsenal de leyes, decretos leyes y regulaciones diversas que se habían dictado en los últimos tres lustros. Ninguna nueva regulación era necesaria para enfrentar la crisis económica, la cual solo podría ser atacada por el propio gobierno desarrollando una política económica distinta a la que la originó.

El decreto de emergencia económica, en efecto, fue dictado por el Presidente de la República en uso de la atribución que le confería el artículo 236.7 de la Constitución para, en Consejo de Ministros "declarar los estados de excepción y decretar la restricción de garantías en los casos previstos en esta Constitución.” Dichos estados de excepción se regulan en los artículos 337 y siguientes de la misma Constitución, donde se precisa que se pueden dictar cuando se trata de emergencia económica, en casos de "circunstancias económicas extraordinarias que afecten gravemente la vida económica de la Nación," (art. 337), en el marco general de circunstancias "que afecten gravemente la seguridad de la Nación, de las instituciones y de los ciudadanos y ciudadanas, a cuyo respecto resultan insuficientes las facultades de las cuales se disponen para hacer frente a tales hechos" (art. 337).

En tal caso de emergencia económica, como en todos los otros, la Constitución autoriza al Presidente de la República para restringir temporalmente las garantías económicas consagradas en esta Constitución (art. 337), en cuyo caso está obligado en el texto mismo del decreto a "regular el ejercicio del derecho cuya garantía se restringe" (art. 339). 
Ahora bien, si se analiza el contenido del Decreto № 2.184 de fecha 14 de enero de 2016, lo que se evidencia es que el mismo, en realidad, no fue un decreto de "emergencia económica" en los términos antes mencionados, porque todo lo que en el mismo se anunció y enunció pudo haberse ejecutado por el gobierno, el cual disponía de todas las leyes, decretos leyes y regulaciones imaginables, con facultades suficientes para hacer frente a los hechos que supuestamente habrían originado la crisis económica en el país. Es decir, si algo no podía afirmarse seriamente era que en el Estado centralista, socialista, totalitario y militarista que se desarrolló en los últimos lustros, supuestamente resultaban "insuficientes las facultades de las cuales se disponen para hacer frente a tales hechos." Esta fue la primera gran mentira del decreto de estado de emergencia económica, como fue la también mentira contenida en los diversos decretos de emergencia económica dictados en los Estados fronterizos durante 2015, ${ }^{3}$ que no condujeron a nada ni resolvieron la crisis económica, sino impusieron un cierre de la frontera para los ciudadanos de a pie, violándoseles impunemente sus derechos y garantías constitucionales, tanto a los colombianos como a los venezolanos.

Fue en el marco de esa gran mentira que encajó, por ejemplo, el enunciado del artículo 1 del Decreto No 2184 de enero de 2016, al afirmar que el estado de emergencia económica decretado, era para:

(i) "que el Ejecutivo disponga de la atribución para adoptar las medidas oportunas que permitan atender eficazmente la situación excepcional, extraordinaria y coyuntural por la cual atraviesa la economía venezolana," de manera que: "permita asegurar a la población el disfrute pleno de sus derechos y el libre acceso a bienes y servicios fundamentales e igualmente, mitigar los efectos de la inflación inducida, de la especulación, del valor ficticio de la divisa, el sabotaje a los sistemas de distribución de bienes y servicios,"

$3 \quad$ Véase Allan R. Brewer-Carías, "La masacre de la Constitución y la aniquilación de las garantías de los derechos fundamentales. Sobre la anómala, inefectiva e irregular decisión del Ejecutivo Nacional de decretar un Estado de Excepción en la frontera con Colombia en agosto de 2015, y la abstención del Juez Constitucional de controlar sus vicios de inconstitucionalidad," 29 de agosto de 2015, en www.allanbrewer-carias.com 
(ii) y "también contrarrestar las consecuencias de la guerra de los precios petroleros, que ha logrado germinar al calor de la volátil situación geopolítica internacional actual, generando una grave crisis económica."

Por supuesto, en cuanto a las segundas medidas, no era necesario ser economista ni especialista en comercio internacional para apreciar que con un decreto de estado de emergencia, ni con las decisiones que conforme al mismo podían adoptarse en el marco del Estado venezolano, se podía contrarrestar en forma alguna la baja de los "precios petroleros," cuya fijación depende exclusivamente del mercado internacional, que no controla nadie en particular, sino solo el mercado.

Y en cuanto a las primeras medidas, todas, absolutamente todas se podían enfrentar con un cambio de política económica, con todos los instrumentos de los cuales disponía el Estado para efectuar dicho cambio, de manera de aumentar la producción nacional, bajar la dependencia de importaciones, sincerar el valor de la moneda, sin lo cual no podría haber decreto alguno capaz de asegurarle a la población su derecho de acceso a bienes y servicios fundamentales; ni poder mitigar los efectos de la "inflación inducida; de la especulación, del valor ficticio de la divisa, el sabotaje a los sistemas de distribución de bienes y servicios," todo lo cual había sido inducido por el propio gobierno y se debía a la errada política económica del Estado que se adoptó en el país.

Para reorientar la política económica, por supuesto, nadie podría argumentar que "resultan insuficientes las facultades de las cuales se disponen [en el seno del gobierno] para hacer frente a tales hechos" (art. 337). Y todo ello, se confirmó con los enunciados contenidos en el artículo 2 del Decreto, donde solo se "anunciaron" las medidas que se supuestamente se iban a tomar, lo que confirmó que constitucionalmente no era un decreto de estado de emergencia económica, sino un anuncio de medidas que bien podía haber formulado el Presidente ante la Asamblea Nacional, en su mensaje anual, que era donde correspondía. 
Pero no. Se optó por decretar un estado de emergencia o de excepción, solo anunciándose "medidas" a ser adoptadas en el futuro, pero sin indicarse nada sobre el cambio de rumbo de la política económica que había originado las "circunstancias excepcionales," sino más bien, reafirmando la misma línea errada de intervencionismo estatal.

Ello se constata simplemente con analizar cuáles fueron las "medidas que considere convenientes" adoptar el Ejecutivo, y que se anunciaron en el artículo $2^{\circ}$ del Decreto "como consecuencia de la declaratoria del estado de emergencia económica," que debían estar todas "orientadas a proteger y garantizar los derechos y el buen vivir de las familias, de los niños, niñas y adolescentes y de los adultos mayores":

1. En primer lugar "disponer los recursos provenientes de las economías presupuestarias del ejercicio económico financiero 2015," con determinadas finalidades, para lo cual bastaba hacer uso de las atribuciones previstas en Ley Orgánica de Administración Financiera del Sector Público.

2. En segundo lugar, asignar recursos extraordinarios a proyectos previstos o no en la Ley de Presupuesto a los órganos y entes de la Administración Pública, para determinados sectores de actividad y Misiones, para lo cual bastaba hacer uso de las atribuciones previstas en Ley Orgánica de Administración Financiera del sector Público.

3. Diseñar e implementar medidas especiales, de aplicación inmediata, para la reducción de la evasión y la elusión fiscal, para lo cual bastaba aplicar las atribuciones de fiscalización y control establecidas en el Código Orgánico Tributario y en las normas que regulan el SENIAT.

4. Dispensar de las modalidades y requisitos propios del régimen de contrataciones públicas para agilizarlas, para lo cual bastaba aplicar las normas de excepción que son abundantísimas previstas en la Ley de Contrataciones Públicas.

5. Dispensar de los trámites, procedimientos y requisitos para la importación y nacionalización de mercancías, cumpliendo con los requerimientos fitosanitarios pertinentes, para lo cual bastaba aplicar la Ley Orgánica de Aduanas y la Ley de Simplificación de Trámites Administrativos. 
6. Implementar medidas especiales para agilizar el tránsito de mercancías por puertos y aeropuertos de todo el país, para lo cual también bastaba aplicar la Ley Orgánica de Aduanas y la Ley de Simplificación de Trámites Administrativos.

7. Dispensar de los trámites cambiarios establecidos por CENCOEX y por el Banco Central de Venezuela, a órganos y entes del sector público o privado, para garantizar la importación, para lo cual bastaba aplicar la Ley de Ilícitos Cambiarios y reformular los Convenios Cambiarios entre el Banco Central de Venezuela y el Ejecutivo nacional.

8.a. Requerir a empresas del sector público incrementar sus niveles de producción, para lo cual bastaba aplicar la Ley Orgánica de la Administración Pública, dando las instrucciones pertinentes a través de los diversos órganos de adscripción;

8.b. Requerir de las empresas del sector privado incrementar sus niveles de producción, para lo cual no valía decreto ni “orden” ejecutiva alguna, sino estímulo y fomento como política de Estado.

9.a Adoptar las medidas necesarias para asegurar el acceso oportuno de la población a bienes de primera necesidad, para lo cual bastaba estimular la producción nacional por el sector privado y permitirle el acceso a las divisas para importar, en un marco de sinceración del valor de la moneda, que solo un cambio de política económica podía provocar, sin necesidad de decreto alguno de emergencia.

9.b. Poder requerir "de las personas naturales y jurídicas propietarias o poseedoras, los medios de transporte, canales de distribución, centros de acopio, beneficiadoras, mataderos y demás establecimientos, bienes muebles y mercancías que resulten necesarios para garantizar el abastecimiento oportuno de alimentos a las venezolanas y los venezolanos, así como de otros bienes de primera necesidad," para lo cual no era necesario decreto alguno de emergencia, pudiendo aplicarse las muy inconvenientes medidas ya establecidas en todas las leyes limitativas de la libertad económica dictadas en los últimos años, entre las cuales estaba la Ley de Precios Justos.

10. Adoptar las medidas necesarias para estimular la inversión extranjera "en beneficio del desarrollo del aparato productivo nacional, así como 
las exportaciones de rubros no tradicionales, como mecanismo para la generación de nuevas fuentes de empleo, divisas e ingresos," para lo cual bastaba aplicar por ejemplo, la Ley de Inversión Extranjera dictada en sustitución de la Ley de Promoción y Protección de la Inversión, así como la Ley de Promoción de la Inversión mediante Concesiones.

11. Desarrollar, fortalecer y proteger el Sistema de Misiones y Grandes Misiones Socialistas, para lo cual bastaba aplicar la Ley Orgánica de Misiones y Grandes Misiones.

Es decir, para dictar e implementar las medidas anunciadas, el Ejecutivo no carecía de las facultades necesarias para atender su implementación. Le bastaba aplicar las leyes dictadas, casi todas incluso reformadas recientemente, lo que evidenciaba que el decreto de emergencia económica, no fue tal, sino un simple anuncio de medidas que pudo el Ejecutivo dictar aplicando las leyes.

De resto, el Decreto, en el artículo 3 simplemente "anunció" que con base en los mismos artículos 337 y siguientes de la Constitución podía dictar en el futuro otras medidas de excepción, para lo cual no era necesario anuncio alguno, pues son facultades constitucionales; en el artículo 4 repitió lo que ya estaba en las leyes que regulan a la Administración Pública en materia de la necesaria coordinación entre órganos y entes públicos para implementar decisiones; en el artículo 5, se repitió lo que la Constitución establece sobre la obligación de los órganos de los Poderes Públicos de colaborar en el cumplimiento del decreto, con el incomprensible agregado de la "Fuerza Armada Nacional Bolivariana," como si fuese algo distinto que existiese fuera del Poder Público; y en el artículo 6, se convocó a la participación activa del pueblo en la "la consecución de los más altos objetivos de consolidación de la patria productiva y económicamente independiente," enumerándose órganos regulados legalmente como formando parte del llamado "Poder Popular," pero con el agregado, esta vez de uno que no existía y ras el denominado "Parlamento Comunal."

Y nada más, salvo repetir en el artículo 7 lo que dice la Constitución sobre la remisión del decreto "a la Asamblea Nacional, a los fines de su consideración y aprobación, dentro de los ocho (8) días siguientes a su publicación" lo que ocurrió el 14 de enero de 2016, a los efectos del control político del decreto; y en 
el artículo 8 lo que también dice la Constitución sobre la remisión del decreto a "la Sala Constitucional del Tribunal Supremo de Justicia, a los fines de que se pronuncie sobre su constitucionalidad, dentro de los ocho (8) días siguientes a su publicación en la Gaceta Oficial."

\subsection{Algunos principios sobre el control político de los decretos de estados de excepción}

El artículo 339 de la Constitución, en efecto, dispone que el decreto que declare el estado de excepción:

"será presentado, dentro de los ocho días siguientes de haberse dictado, a la Asamblea Nacional o a la Comisión Delegada, para su consideración y aprobación, y a la Sala Constitucional del Tribunal Supremo de Justicia, para que se pronuncie sobre su constitucionalidad."

Se establece así, un doble régimen general de control parlamentario y judicial sobre los decretos de excepción, el cual se desarrolla en la Ley Orgánica de los Estados de Excepción, ${ }^{4}$ estableciendo normas particulares en relación con el control por parte de la Asamblea Nacional, por parte de la Sala Constitucional del Tribunal Supremo y por parte de los jueces de amparo. ${ }^{5}$ Además, respecto del control político, la norma prevé que el Decreto puede ser "revocado por [...] la Asamblea Nacional o por su Comisión Delegada," antes del término señalado para su duración, "al cesar las causas que lo motivaron."

En cuanto al control inicial de orden político debe notarse que la Constitución exige que el decreto se remita a la Asamblea, "dentro de los ocho días siguientes de haberse dictado," fecha que no necesariamente es el da la publicación, que podría ocurrir posteriormente. Sin embargo, las leyes y actos normativos del Estado solo entran en vigencia a la fecha de su publicación, no

G.O. $\mathrm{N}^{\mathrm{o}} 37.261$ del 15 de agosto de 2001.

Véase sobre ello lo que hemos expuesto en Allan R. Brewer-Carías, La Constitución de 1999: Estado Democrático y Social de Derecho, Colección Tratado de Derecho Constitucional, Tomo VII,. Fundación de Derecho Público, Editorial Jurídica Venezolana, Caracas 2014; y en "El régimen constitucional de los estados de excepción" en Víctor Bazan (Coordinador), Derecho Público Contemporáneo. Libro en Reconocimiento al Dr. German Bidart Campos, Ediar, Buenos Aires, 2003, pp. 1137-1149. 
de su emisión, lo que se aplica como regla también a los Decretos de estados de excepción a los cuales se les otorga el rango de decreto ley.

Los ocho días para la remisión del decreto a la Asamblea Nacional por el Presidente de la República, conforme lo precisó el artículo 31 de la Ley Orgánica de los Estados de Excepción, se cuentan como "días continuos siguientes a aquel en que haya sido dictado," teniendo la remisión a la Asamblea por objeto "su consideración y aprobación," lo que corresponde hacer a la Asamblea incluso si el Presidente de la República no diere cumplimiento al mandato establecido durante el lapso mencionado, en cuyo caso, conforme a la Ley Orgánica, la Asamblea Nacional debe pronunciarse de oficio (art. 26).

La Constitución le atribuyó en esta forma al órgano parlamentario la potestad de control político sobre los decretos de estado de excepción, asignándole el poder de aprobarlos, y por supuesto de improbarlos. Cuando la Constitución dispone que el decreto se remita a la Asamblea "para su consideración y aprobación,” es por supuesto para su consideración, y como derivado de ello, para su aprobación o improbación. De lo contrario no sería control alguno, sino una simple rúbrica.

En todo caso, la decisión de la Asamblea de aprobar o improbar el Decreto, conforme a la Ley Orgánica, debe adoptarse por la mayoría absoluta de los diputados presentes en sesión especial que se debe realizar sin previa convocatoria, dentro de las 48 horas de haberse hecho público el decreto (art. 27), es decir, de su publicación en Gaceta Oficial. Sin embargo, en forma evidentemente incongruente con este término legal perentorio que no se ajusta al constitucional de ocho días, la Ley Orgánica dispone que si por caso fortuito o causa de fuerza mayor la Asamblea Nacional no se pronunciare dentro de los ocho días "continuos siguientes" a la recepción del decreto, éste se debe entender aprobado. Se establece así, la figura del silencio parlamentario positivo con efectos aprobatorios tácitos, pero dando por sentado que la Asamblea debe pronunciarse aprobando o no el decreto en el término de ocho días, pasado el cual la Ley presume su tácita aprobación.

Por tanto, estaba fuera de toda duda que el decreto de estado de excepción podía ser rechazado por la Asamblea, negándole su aprobación; de eso se trataba 
el control político; en cuyo caso el decreto cesaba de tener vigencia y no podía producir efectos jurídicos. No tenía fundamento alguno, por tanto, lo afirmado sin argumentación por la Sala Constitucional en sentencia № 7 dictada el 11 de febrero de 2016 con ocasión de resolver un recurso de interpretación de las normas relativas a los estados de excepción, ${ }^{6}$ que se comenta más adelante, en el sentido de que el "control político de la Asamblea Nacional sobre los decretos que declaran estados de excepción no afecta la legitimidad, validez, vigencia y eficacia jurídica de los mismos." Si no lo afecta, de nada valdría entonces establecer el control político, el cual no se limita a la sola posibilidad que tiene la Asamblea de revocar la prórroga del decreto de estado de excepción, antes del término establecido, al cesar las causas que lo motivaron.

Este control político sobre los decretos de los estados de excepción, por supuesto, es completamente distinto al control jurídico constitucional automático y obligatorio que sobre los mismos ejerce la Sala Constitucional del Tribunal Supremo de Justicia, a la cual la Constitución le asignó competencia expresa para "revisar en todo caso, aún de oficio, la constitucionalidad de los decretos que declaren estados de excepción dictados por el Presidente de la República" (artículo 336,6), a cuyo efecto, como lo dice su artículo 339, y el artículo 31 de la Ley Orgánica, el Presidente de la República también debe remitir el decreto dentro de los ocho días continuos siguientes de haberse dictado, a "la Sala Constitucional del Tribunal Supremo de Justicia, para que se pronuncie sobre su constitucionalidad." En el mismo término, el Presidente de la Asamblea Nacional debe enviar a la Sala Constitucional, el Acuerdo mediante el cual se apruebe o rechace el estado de excepción.

En todo caso, si el Presidente de la República o el Presidente de la Asamblea Nacional, según el caso, no daban cumplimiento al mandato establecido en la norma en el lapso previsto, la Sala Constitucional del Tribunal Supremo de Justicia se debía pronunciar de oficio (art. 31). El efecto jurídico de la decisión de la Sala Constitucional que declarase la constitucionalidad del decreto, era que con posterioridad no podía intentarse una acción de inconstitucionalidad contra el mismo.

$\overline{7}$ Véase en http://historico.tsj.gob.ve/decisiones/scon/febrero/184885-07-11216-2016-160117.HTML 
Se trataba, por tanto de dos controles con dos efectos jurídicos distintos que debían efectuarse dentro del mismo lapso de ocho días, sin que hubiera orden alguno en el cual se podían adoptar las decisiones, pudiendo ser cualquiera de ellas antes que la otra. Sin embargo, si la Asamblea Nacional o la Comisión, dentro del término mencionado, decidiere antes que la Sala Constitucional desaprobando el decreto de estado de excepción, la Sala Constitucional del Tribunal Supremo de Justicia debe omitir todo pronunciamiento, declarando extinguida la instancia (art. 33, Ley Orgánica); ${ }^{7}$ de lo que resulta que el control político tiene primacía sobre el control jurídico.

El objeto del control jurídico por parte de la Sala Constitucional, como lo expresamos hace años, es "para revisar la constitucionalidad de los decretos de excepción, es decir, que en su emisión se hubieran cumplido los requisitos establecidos en la Constitución (constitucionalidad formal) y en la Ley Orgánica; y segundo, que el decreto no viole la normativa constitucional ni la establecida en la Ley Orgánica," 8 como por ejemplo, que si en el decreto se restringe una garantía constitucional se dé cumplimiento a la exigencia de que el decreto debe "regular el ejercicio del derecho cuya garantía se restringe" (art.

$7 \quad$ Hemos considerado que esta norma legal es inconstitucional pues establece una limitación al ejercicio de sus poderes de revisión por la Sala, no autorizada en la Constitución, que puede efectuarse de oficio indepen-dientemente de que la Asamblea Nacional haya negado su aprobación. Véase, Allan R. Brewer-Carías, Derecho Constitucional Venezolano. Constitución de 1999, Editorial Jurídica Venezolana, Caracas 2016, Tomo I, pp. Igualmente en el trabajo: "El régimen constitucional de los estados de excepción" en Víctor Bazán (Coordinador), Derecho Público Contem-poráneo. Libro en Reconocimiento al Dr German Bidart Campos, Ediar, Buenos Aires, 2003, pp. 1137-1149. La Sala Constitucional en su sentencia cita esta opinión mía, recogida en el trabajo: "Las Potestades Normativas del Presidente de la República: los Actos Ejecutivos de Orden Normativo" en Tendencias Actuales del Derecho Constitucional, Homenaje a: Jesús María Casal Montbrun (Coordinadores: Jesús María Casal - Alfredo Arismendi A. - Carlos Luis Carrillo), Tomo I, Caracas 2007, pp. 527-528. La Sala citó éste último trabajo, concordando con mi opinión de que la Sala al "revisar la constitucionalidad de los decretos que declaren estados de excepción dictados por el Presidente de la República, se trata de un control de la constitucionalidad automático y obligatorio que la Sala Constitucional debe ejercer incluso de oficio, lo cual puede hacer desde que se dicte y se publique en la Gaceta Oficial, y no sólo al final del lapso indicado ni sólo si no se le remite oficialmente al decreto." La sentencia, con base en ello, de paso declaró por control difuso la inaplicabilidad de dicha norma y ordenó abrir juicio de nulidad contra la misma. Idem. 
339); es decir, que tiene que tener en sí mismo contenido normativo en relación con las restricciones al ejercicio del derecho constitucional respectivo. ${ }^{9}$

\subsection{El control político ejercido por la Asamblea Nacional en relación con el decreto de emergencia económica de enero de 2016}

El Decreto No 2184 de 14 de enero de 2016 antes comentado, mediante el cual se decretó la emergencia económica en el país, fue presentado personalmente por el Presidente de la República a la Asamblea Nacional con ocasión de su comparecencia para presentar su mensaje anual, dentro del término fijado en la Constitución, es decir, el día 15 de enero de 2016, que fue el día siguiente de su emisión. La decisión de control político que debía adoptar la Asamblea Nacional en el sentido de aprobar o improbar el decreto, e independientemente del control jurídico que correspondía ser ejercido por la Sala Constitucional, tenía que producirse entonces necesariamente dentro de los ocho días continuos siguientes a la emisión del decreto (que fue el 14 de enero), es decir, entre el 15 de enero y el 22 de enero de 2016 de manera que si en ese lapso no se producía la decisión expresa de la Asamblea, entonces conforme a la Ley debía considerarse que había sido aprobado tácitamente.

Y efectivamente, en sesión de la Asamblea Nacional del día 22 de enero de 2016 se discutió y aprobó un Acuerdo "con base en el Informe presentado por la Comisión Especial designada para examinar el Decreto o 2184, del 14 de enero de 2016," en el cual, como lo afirmó la Sala Constitucional en la misma sentencia citada, el órgano de representación popular "desaprobó políticamente dicho Decreto." Dicho Acuerdo se tituló como:

"Acuerdo mediante el cual se desaprueba el Decreto № 2184, del 14 de enero de 2016, publicado en la Gaceta Oficial № 6.214 Extraordinario del 14 de enero de 2016, en el que se declaró el Estado de Emergencia Económica en todo el Territorio Nacional."

Idem. 
Conforme al artículo 30 de la Ley Orgánica, dicho Acuerdo parlamentario “entró en vigencia inmediatamente," es decir, el mismo día 22 de enero de 2016, previendo dicha norma que debía ser publicado en la Gaceta Oficial y "difundido en el más breve plazo, por todos los medios de comunicación social, al día siguiente en que haya sido dictado, si fuere posible” (art. 30).

Ello significó, en derecho, que el Decreto No 2184 de 14 de enero de 2016 mediante el cual el Presidente de la República había dictado un estado de excepción que como vimos de su contenido, en realidad no era tal, en todo caso había cesado de producir efectos jurídicos, a pesar incluso de que hubiese sido controlado jurídicamente por la Sala Constitucional y lo hubiese declarado conforme a la Constitución, lo que efectivamente la Sala Constitucional realizó mediante sentencia No 4 del 20 de enero de 2016, en la cual al decir de la propia Sala "declaró el carácter constitucional del referido Decreto Presidencial, y, por ende, garantizando la legitimidad, validez, vigencia y eficacia jurídica del mismo, dentro del marco constitucional."

La Sala, en efecto en dicha sentencia resolvió:

"la constitucionalidad del Decreto sub examine, el cual fue dictado en cumplimiento de todos los parámetros que prevé la Constitución de la República Bolivariana de Venezuela y la Ley Orgánica sobre Estados de Excepción y demás normativas aplicables.”

Sin embargo, la Sala no se quedó en el ejercicio de su control jurídico sino que en forma evidentemente inconstitucional, pasó a ejercer sobre el mimo un "control político" usurpando las funciones de la Asamblea Nacional, al declarar en el mismo párrafo que reconocía:

"su pertinencia, proporcionalidad y adecuación, el cual viene a apuntalar con sólido basamento jurídico y con elevada significación popular, la salvaguarda del pueblo y su desarrollo armónico ante factores inéditos y extraordinarios adversos en nuestro país, de conformidad con la Constitución de la República Bolivariana de Venezuela; sin perjuicio del control posterior que pueda efectuar esta Sala de conformidad con sus atribuciones constitucionales." 


\subsection{El desconocimiento por la Sala Constitucional de la potestad de control político por parte de la Asamblea de los decretos de estado de excepción}

Con posterioridad a la desaprobación del Decreto presidencial de emergencia económica por parte de la Asamblea Nacional, en fecha 3 de febrero de 2016, un grupo de ciudadanos que se identificaron como miembros de Consejos Comunales y de Comunas, acudieron ante la Sala Constitucional, para intentar un "recurso de interpretación de naturaleza constitucional," sobre el artículo 339 de la Constitución, y los artículos 27 y 33 de la Ley Orgánica sobre los Estados de Excepción, a cuyo efecto plantearon, entre otras, "las siguientes dudas" que en síntesis se refieren al ejercicio sobre las potestades de control político por parte de la Asamblea Nacional:

(i) que las normas mencionadas nada establecieron sobre "las consecuencias para el Decreto que declara el estado de excepción" de la desaprobación por parte de la Asamblea Nacional;

(ii) que una vez que el Decreto ha sido "declarado conforme a la Constitución” por la Sala Constitucional, “ ¿entonces en qué consiste la no aprobación de la Asamblea Nacional?”

(iii) que si la decisión del Presidente en una situación de emergencia, el decreto que se dicte puede quedar sujeta a "la potestad evaluativa ya discrecional de la Asamblea Nacional, aun cuando se ha declarado su constitucionalidad?;"

(iv) que si al establecerse la potestad de la Asamblea de revocar el decreto de estado de excepción, no debe considerarse que "es ese el control revocatorio?";

(v) que otorgada facultad de revocar el decreto a la Asamblea, no quiere decir esto que ese "es el control parlamentario político" no pudiendo la aprobación "tener ningún efecto modificatorio o suspensivo, sino más bien prima facie mantener intangible el Decreto, pese a su apreciación política?" y

(vi) que si el Presidente de la República, no es "el único Juez de Mérito de su acto de gobierno o Decreto?". 
Todas esas "dudas," para solicitar a la Sala finalmente que se pronunciase "sobre la vigencia del decreto 2.184 publicado en la Gaceta Oficial N 6.214 Extraordinario de fecha 14 de enero de 2016."

Es decir, ni más ni menos, lo que se solicitó fue mediante un recurso de interpretación constitucional, cuya decisión fue adoptada en violación flagrante a la garantía del debido proceso y al derecho a la defensa, que la Sala se pronunciase sobre la vigencia del Acuerdo de la Asamblea Nacional, que ya había desaprobado el decreto de estado de excepción.

Y ello lo hizo la Sala mediante sentencia No 7 del 11 de febrero de 2016, ${ }^{10}$ en la cual básicamente lo que argumentó fue sobre el control judicial que ella debe hacer sobre los decretos de estados de excepción, que no era el tema planteado ni sobre el cual se le pedía decisión; de manera que luego de copiar citas de autores a diestra y siniestra, considerando que lo planteado era de mero derecho, procedió a decidir sin trámite alguno, reconociendo primeramente que si bien en la Constitución no se indica expresamente que la Asamblea Nacional al ejercer el control político sobre los decretos de estados de excepción, puede improbarlos,

"por lógica jurídica, la referencia expresa a la aprobación, en la Constitución de 1999, apareja la posibilidad contraria, es decir, la de la desaprobación, tal como lo ha reconocido esta Sala."

Y de allí pasó la Sala a deducir una consecuencia también lógica, y que es que "la aprobación o desaprobación del decreto de estado de excepción, por parte de la Asamblea Nacional, lo afecta desde la perspectiva del control político y, por ende, lo condiciona políticamente, pero no desde la perspectiva jurídicoconstitucional," lo que sin duda corresponde a la Sala Constitucional, sin que aquél control político invalide este, aun cuando si se produce con anterioridad, éste ya no procede.

$10 \quad$ Véase en http://historico.tsj.gob.ve/decisiones/scon/febrero/184885-07-11216-2016 -16-011.HTML. 
Pero a pesar de estas premisas lógicas, de seguida la Sala Constitucional pasó a concluir, contradiciéndolas, usurpando la función del Poder Legislativo y contradiciendo la Constitución, que a ella le correspondía en exclusiva decidir sobre "legitimidad, validez y vigencia jurídico-constitucional," lo cual a su juicio "no le corresponde efectuar al Poder Legislativo Nacional," limitando el control político de este solo a poder "revocar" los decretos de excepción al cesar las causas que lo motivaron. Para ello, más adelante, en su sentencia, después de citar a Locke y a Montesquieu, la Sala agregó en su razonamiento limitativo sobre el control político que corresponde a la Asamblea, que

"el Texto Constitucional vigente sólo se refiriere al sometimiento del decreto que declara estado de excepción a la Asamblea Nacional para su consideración y aprobación, y sólo alude, en el contexto de la prórroga de ese estado, a la posibilidad de revocatoria "por el Ejecutivo Nacional o por la Asamblea Nacional o por su Comisión Delegada, antes del término señalado, al cesar las causas que lo motivaron."

Argumentando de paso y adicionalmente que, incluso, dicha revocación podría ser sometida a control de constitucionalidad ante la Sala Constitucional, reafirmando que a ella corresponde "el control supremo de los actos del Poder Público" para concluir, en definitiva que el control político por parte de la Asamblea Nacional es "un control relativo," que supuestamente está sometido al control constitucional. En cambio el control que ejerce la Sala Constitucional,

"además de ser un control jurídico y rígido, es absoluto y vinculante, al incidir en la vigencia, validez, legitimidad y efectividad de los actos jurídicos, incluyendo los decretos mediante los cuales se establecen estados de excepción."

Y después de estos "razonamientos" con los cuales supuestamente la Sala habría dado respuesta "a las inquietudes interpretativas presentadas," sin más, terminó afirmando que:

"el control político de la Asamblea Nacional sobre los decretos que declaran estados de excepción no afecta la legitimidad, validez, vigencia y eficacia jurídica de los mismos; y el Texto Fundamental prevé de forma 
expresa que la Asamblea Nacional puede revocar la prórroga del decreto de estado de excepción, antes del término señalado, al cesar las causas que lo motivaron."

O sea, la Sala simplemente desconoció la Constitución y el sentido del control político que tiene la Asamblea Nacional para poder aprobar o improbar el decreto de excepción, reduciendo dicho control político de la Asamblea pura simplemente, a solo poder revocar posteriormente el decreto de estado de excepción, pero incluso precisando que en dicho caso, podía ser objeto de control de la constitucionalidad por parte de la misma Sala; y de allí, a pesar de la ausencia de motivación jurídica, concluyó la Sala que el Decreto No 2.184 de 14 de enero de 2016, que declaró el estado de emergencia económica en todo el territorio nacional:

"entró en vigencia desde que fue dictado y su legitimidad, validez, vigencia y eficacia jurídico-constitucional se mantiene irrevocablemente incólume, conforme a lo previsto en el Texto Fundamental."

Para terminar, la Sala Constitucional se refirió a los lapsos para decidir sobre el control político por parte de la Asamblea Nacional, y a pesar de que la decisión de improbar el decreto de emergencia económica lo adoptó la Asamblea mediante acuerdo el día 22 de enero de 2016, es decir, dentro del lapso constitucional de 8 días continuos a partir del 14 de enero, incurrió en la insensatez de decir que como el artículo 27 hace referencia a una sesión especial que debe realizarse sin previa convocatoria dentro de las cuarenta y ocho horas de "haberse hecho público el decreto," y la Asamblea no decidió sino dentro del lapso constitucional de ocho días, entonces, además, la misma

“vulneró la legalidad procesal, la seguridad jurídica y el debido proceso consagrado en el artículo 49 Constitucional, pilares fundamentales del Estado Constitucional de Derecho (vid. arts. 2, 7, 137, 334, 335 y 336 del Texto Fundamental), viciando de nulidad por inconstitucionalidad el proceso que culminó con el constitucionalmente írrito acuerdo dictado por la máxima representación del Poder Legislativo Nacional, el 22 de enero de 2016." 
Con ello, dijo la Sala contra toda lógica, que la Asamblea Nacional habría omitido "una forma jurídica esencial contemplada en la ley," y desconociendo que efectivamente había decidido dentro del lapso constitucional, afirmó sin base alguna que se habría producido el "silencio positivo" lo cual es falso, pues solo está previsto cuando no se toma la decisión en el lapso de ocho días, concluyendo entonces con la afirmación de que "la Asamblea Nacional no cumplió oportunamente y, en fin, dentro de los límites constitucionales y legales, con el control político del referido decreto."

Agregó además la Sala que como la misma había realizado el control jurídico dentro del mismo lapso de ocho días continuos siguientes a aquel en que se dictó el Decreto,

"no existe objetivamente, además, controversia constitucional entre órganos del Poder Público que resolver con relación a esa situación fáctica, a pesar de la írrita decisión negativa de la Asamblea Nacional pronunciada el día 22 de enero de 2016, que debe entenderse como inexistente y sin ningún efecto jurídico-constitucional."

Y todo ello, porque a juicio de la Sala:

"el Poder Ejecutivo ejerció su competencia de dictar el decreto de emergencia económica, el Poder Legislativo no cumplió con su obligación de considerarlo en sesión especial dentro de las 48 horas después de haberse hecho público el decreto y la Sala Constitucional ejerció su atribución de declarar la constitucionalidad del mismo de manera oportuna, mediante sentencia n. ${ }^{\circ} 4$ del 20 de enero de $2016 . "$

Así, la Sala Constitucional, con ocasión de decidir un recurso de interpretación constitucional, terminó declarando "irrito," es decir, sin validez ni fuerza obligatoria, o en palabras de la propia Sala "inexistente y sin ningún efecto jurídico-constitucional" el Acuerdo de la Asamblea Nacional improbando el Decreto de Emergencia Económica, y todo ello, en un proceso en el cual no podía "anular" un acto de la Asamblea Nacional, sin seguir el procedimiento de los juicios de nulidad, por lo que, usando las propias palabras de la Sala Constitucional en la sentencia: "vulneró la legalidad procesal, la seguridad 
jurídica y el debido proceso consagrado en el artículo 49 Constitucional, pilares fundamentales del Estado Constitucional de Derecho (vid. arts. 2, 7, 137, 334, 335 y 336 del Texto Fundamental)," viciando de nulidad por inconstitucionalidad el proceso que culminó con la "constitucionalmente írrita” sentencia de fecha 11 de enero de 2016.

Pero como la Sala Constitucional no tiene quien la controle, pudo cometer esta y las otras inconstitucionalidades que analizamos en este libro, impunemente.

Debe destacarse, finalmente, que la Sala Constitucional en ejercicio del control difuso de constitucionalidad, también resolvió en su sentencia desaplicar el artículo 33 de la Ley Orgánica de Estados de Excepción que establece:

Artículo 33. La Sala Constitucional del Tribunal Supremo de Justicia omitirá todo pronunciamiento, si la Asamblea Nacional o la Comisión Delegada desaprobare el decreto de estado de excepción o denegare su prórroga, declarando extinguida la instancia.

Para ello, la Sala se basó en una opinión del profesor Ramón José Duque Corredor y en otra opinión de quien esto escribe, que cita, en la cual consideré que esta norma podía considerarse inconstitucional:

“pues establece una limitación al ejercicio de sus poderes de revisión por la Sala, no autorizada en la Constitución. La revisión, aún de oficio, del decreto de estado de excepción puede realizarse por la Sala Constitucional, independientemente de que la Asamblea Nacional haya negado su aprobación, máxime si el decreto, conforme a la Ley Orgánica al entrar en vigencia 'en forma inmediata' incluso antes de su publicación, ha surtido efectos."11

Con base en ello, para decidir que "lo ajustado al orden constitucional es desaplicar por control difuso de la Constitución” dicha norma del artículo 33 de la Ley Orgánica, la Sala Constitucional indicó que:

$11 \quad$ Véase Allan R. Brewer-Carias, "Las Potestades Normativas del Presidente de la República: Los Actos Ejecutivos de Orden Normativo" en Tendencias Actuales del Derecho Constitucional. tomo I, Universidad católica Andrés Bello, Caracas, 2007, pp. 527-528. 
“Tal como concluye el referido autor, y con lo cual concuerda esta máxima instancia constitucional, revisar la constitucionalidad de los decretos que declaren estados de excepción dictados por el Presidente de la República, se trata de un control de la constitucionalidad automático y obligatorio que la Sala Constitucional debe ejercer incluso de oficio, lo cual puede hacer desde que se dicte y se publique en la Gaceta Oficial, y no sólo al final del lapso indicado ni sólo si no se le remite oficialmente al decreto. Por lo que afirma que el artículo 33 de la Ley Orgánica sobre Estados de Excepción, el cual señala que la Sala Constitucional del Tribunal Supremo de Justicia omitirá todo pronunciamiento si la Asamblea Nacional o la Comisión Delegada desaprobare el decreto de estado de excepción o denegare su prórroga, declarando extinguida la instancia, es, en efecto, inconstitucional, pues establece una limitación al ejercicio de sus poderes de revisión por la Sala, no autorizada en la Constitución y que quebranta la propia supremacía y protección última del Texto Fundamental."

Podía la Sala, sin duda, ejercer dicho control difuso de constitucionalidad sobre la primacía que la Ley otorgó al control político sobre el control jurídico, pero lo que no podía era restringir, violando la Constitución, el control político que correspondía a la Asamblea Nacional.

\subsection{La declaración de constitucionalidad de la prórroga del Decreto de Emergencia Económica, y su obligatoriedad para el Poder Público (incluyendo la Asamblea Nacional) decretada por la Sala Constitucional}

El mencionado Decreto estado de emergencia económica en todo el territorio nacional No 2.184 de 14 enero de 2016, fue prorrogado por 60 días más, mediante el Decreto № 2.270 del 11 de marzo de $2016,{ }^{12}$ y conforme a las mismas normas constitucionales antes mencionadas, fue sometido a la Sala Constitucional del Tribunal Supremo de Justicia para decidir sobre su constitucionalidad.

12 Véase Gaceta Oficial No 6219 Extra de 11 de marzo de 2016. 
La Sala Constitucional mediante sentencia No 184 de 17 de marzo de $2016,{ }^{13}$ procedió a declarar la constitucionalidad del decreto de prórroga, agregando que ello "motiva el respaldo orgánico de este cuerpo sentenciador de máximo nivel de la Jurisdicción Constitucional, hacia las medidas contenidas en el Decreto objeto de examen de constitucionalidad;" terminando con la declaración general de que dicho Decreto "deberá ser acatado y ejecutado por todo el Poder Público," lo que incluía por supuesto a la Asamblea Nacional, desconociendo asísu competencia constitucional para efectuar el control político del decreto y poder improbarlo; y reafirmando para que no quedase duda, que "en su condición de máxima y última intérprete de la Constitución [...] sus decisiones sobre dichas normas y principios son estrictamente vinculantes en función de asegurar la protección y efectiva vigencia de la Carta Fundamental."

Con la sentencia, en definitiva, la Sala Constitucional vació totalmente a la Asamblea Nacional de su potestad de ejercer el control político sobre los estados de excepción, violando abierta y arteramente la Constitución.

\section{Los ataques de la Sala Constitucional contra la Asamblea Nacional cercenándole sus poderes de control político sobre el gobierno y de la administración pública}

\subsection{El intento fallido de la Asamblea de ejercer el control político sobre el Gobierno y la Administración para estudiar el decreto de emergencia económica}

Durante los días siguientes al de la comparecencia del Presidente de la República ante la Asamblea Nacional para presentar su Mensaje anual (15 de enero de 2016), y con ocasión de la consignación ante la Asamblea del Decreto de Estado de Emergencia Económica, la Asamblea Nacional, como le corresponde constitucionalmente, requirió la comparecencia de los Ministros del área económica ante sus Comisiones, precisamente a los efectos de considerar el decreto de estado de emergencia económica que se había dictado a los efectos de su aprobación o improbación.

\footnotetext{
13 Véase en http://historico.tsj.gob.ve/decisiones/sconmarzo/186437-184-17316-2016-16 $-0038 . h t m l$.
} 
La respuesta del gobierno fue ignorar los requerimientos de la Asamblea, por lo cual, el 21 de enero de 2016, que era el día anterior al vencimiento del lapso para que la Asamblea emitiese su Acuerdo aprobando o improbando el mencionado decreto, el Presidente de la Asamblea resumió la situación de desacato del Poder Ejecutivo, expresando según reseñaron los medios que:

"Es muy grave que se nieguen los ministros y el gobierno a esta comparecencia pública, que es constitucional y legal. Esto es muy grave, es un desacato. Debe ser que las informaciones que tienen que dar al país son muy graves y malas, pero no pueden negar la realidad de Venezuela", afirmó.

Ramos Allup indicó que el vicepresidente de la República, Aristóbulo Istúriz, fue quien le informó que los ministros no asistirían. El gobierno solicitaba que la comparecencia fuera a puerta cerrada. "Querían que se hiciera sin la presencia de los medios y nos negamos rotundamente a semejante petición. La AN es un espacio abierto para la presencia de todos los medios, nacionales e internacionales", dijo.

El presidente de la AN aclaró que no se trataba de un "reality show," como lo dijo Héctor Rodríguez: "Se trata de responder a preguntas escritas, de una manera muy seria y formal. Lamentamos muchísimo que se haya privado al país en directo, por parte de los propios ministros, de cuál es la realidad del país."

La Asamblea Nacional tiene hasta mañana a las 12:00 de la noche para aprobar o no el Decreto de Emergencia Económica, presentado por el presidente Nicolás Maduro.

Ante la falta de tiempo para convocar a una nueva comparecencia, Ramos Allup informó que la comisión tomará una decisión con la información que disponga.

"Nos reuniremos con la comisión, lo discutiremos en plenaria y tomaremos una decisión," dijo." ${ }^{14}$

$14 \quad$ Véase en https://www.facebook.com/permalink.php?id=374440365912-712\&story_ fbid=999122600111149. 
El tema del evidente desacato de los Ministros ante los requerimientos de la Asamblea, sin embargo, fue decidido por la Sala Constitucional del Tribunal Supremo de Justicia, pero insólitamente, no garantizando lo que expresa la Constitución, sino en contra de ella, limitando y reglamentando inconstitucionalmente las potestades de control político de la Asamblea Nacional sobre el gobierno y la Administración Pública.

En efecto, la Sala Constitucional del Tribunal Supremo, mediante sentencia No 9 del $1^{\circ}$ de marzo de 2016 dictada con ocasión de un "Recurso de interpretación" abstracta de los artículos 136, 222, 223 y 265 la Constitución intentado por un grupo de ciudadanos, ${ }^{15}$ en violación de las más elementales y universales principios que rigen la administración de justicia, procedió a cercenar y restringir las potestades de control político de la Asamblea Nacional, sobre el Gobierno y la Administración Pública, materialmente liberando a los Ministros de su obligación de comparecer ante la Asamblea cuando se les requiera para investigaciones, preguntas e interpelaciones; $y$ adicionalmente como se verá más adelante, negándole a la Asamblea su potestad de auto control sobre sus propios actos parlamentarios.

Y ello lo hizo, en primer lugar, utilizando de nuevo una forma procesal viciada para ejercer el control de constitucionalidad de los actos estatales como es el llamado "recurso de interpretación" abstracta de la Constitución, con el que ha terminado declarando nulos unos actos actuales y "futuros" de la Asamblea Nacional.

En segundo lugar, la decisión la dictó la Sala Constitucional, en contra de la Asamblea Nacional, sin siquiera haber oído previamente a la misma a través

$15 \quad$ Véaseenhttp://historico.tsj.gob.ve/decisiones/scon/marzo/185627-09-1316-2016-16-0153. HTML Véase los comentarios en Allan R. Brewer-Carías, "El ataque de la Sala Constitucional contra la Asamblea Nacional y su necesaria e ineludible reacción. De cómo la Sala Constitucional del Tribunal Supremo pretendió privar a la Asamblea Nacional de sus poderes constitucionales para controlar sus propios actos, y reducir inconstitucionalmente sus potestades de control político sobre el gobierno y la administración pública; y la reacción de la Asamblea Nacional contra a la sentencia No 9 de 1-3-2016," en http:// www.allanbrewercarias.com/Con-tent/449725d9-f1cb-474b-8ab2-41efb849fea3/ Content/Brewer.\%20El\%20ataque\%20Sala\%20Constitucional\%20v.\%20Asamblea\%20 Nacional.\%20SentNo.\%209\%201-3-2016).pdf. 
de sus representantes, violando el derecho al debido proceso y a la defensa, que son de carácter absoluto, en términos de la propia Sala.

En tercer lugar, al conocer del recurso y dictar sentencia, la Sala Constitucional actuó en el caso, en violación del más elemental principio de justicia natural, actuando como juez y parte, pues precisamente a lo que se refirió el recurso era a la potestad de la Asamblea de revocar el inconstitucional nombramiento de algunos de los Magistrados que precisamente debían firmar la sentencia.

En cuarto lugar, al dictar normas sobre el funcionamiento de la Asamblea y el ejercicio de sus poderes de control sobre el Gobierno y la Administración Pública, lo que sólo puede hacer la propia Asamblea Nacional, usurpando así la función normativa de la Asamblea que solo puede materializarse en el reglamento interior y de debates, y de paso, declarar como inconstitucionales algunas previsiones del Reglamento Interior y de Debates de la Asamblea y de la Ley sobre el Régimen para la Comparecencia de Funcionarios Públicos ante la Asamblea Nacional o sus Comisiones, todo con el objeto de encasillar y restringir las potestades de control político de la Asamblea sobre el Gobierno y la Administración Pública; y de cercenarle a la Asamblea la potestad de controlar y revisar sus propios actos cuando estén viciados de nulidad absoluta, y revocarlos en consecuencia.

\subsection{El viciado uso del llamado recuso de interpretación constitucional para ejercer el control de constitucionalidad, violando además, la garantía del debido proceso}

Desde que la Sala Constitucional inventó al margen de la Constitución el llamado "recurso de interpretación" abstracta de la Constitución mediante la sentencia No 1077 del 22 de septiembre de 2000 (caso: Servio Tulio León), el cual puede ser intentado por cualquier persona, incluso el Estado mismo a través de la Procuraduría General de la República, para buscar un pronunciamiento abstracto, es decir, sin referencia a caso concreto alguno y sin debate ni confrontación de opiniones de los que puedan estar interesados en la "interpretación," hemos criticado la institución, como un diabólico instrumento mediante el cual la Sala Constitucional bajo la excusa de la 
interpretación, ${ }^{16}$ administra justicia "a la carta," según lo que les apetezca a los propios Magistrados de la Sala o lo que le provoque al propio gobierno, usando para ello a veces peticiones prefabricadas formuladas por cualquier persona "amiga" siempre dispuesta a presentar un escrito ya elaborado para "litigar" sin litigar, o del propio representante del Estado.

$\mathrm{Y}$ eso es lo que ha ocurrido en este caso en el cual, tres abogados, presumiblemente hermanos por llevar los mismos apellidos, actuando según la Sala "en su condición de integrantes del sistema de justicia, como ciudadanos interesados en el adecuado funcionamiento de los poderes públicos," sólo argumentando que tenían "dudas" de lo que pudieran decir los artículos 136, 222, 223 y 265 de la Constitución. El recurso de interpretación lo intentaron el 17 de febrero, y ya el 23 de febrero la Sala había designado Ponente, desarrollándose entonces un "proceso constitucional clandestino" como "de mero derecho," del cual solo estuvieron enterados los recurrentes y el Ponente, y nadie más. El "proceso" tuvo por objeto nada más y nada menos que cercenarle a la Asamblea Nacional, es decir, a los representantes de un pueblo que se rebeló políticamente el 6 de diciembre de 2015, dándole a la oposición la mayoría calificada de la Asamblea, sus poderes parlamentarios de control sobre el Gobierno y la Administración Pública, y además, sobre sus propios actos.

Aun cuando en la "demanda," los demandantes también solicitaron interpretación sobre el alcance de las potestades de control político de la Asamblea Nacional en relación con los otros Poderes Públicos. A pesar de que el control político de la Administración Pública que la Asamblea tiene constitucionalmente asignado comprende no sólo la que se encuentra en el

$16 \quad$ Véase Allan R. Brewer-Carías, “Quis Custodiet Ipsos Custodes: De la interpretación constitucional a la inconstitucionalidad de la interpretación," en Revista de Derecho Público, $\mathrm{N}^{\circ}$ 105, Editorial Jurídica Venezolana, Caracas 2006, pp. 7-27. Véase además sobre ello, e trabajo "La ilegítima mutación de la Constitución por el juez constitucional: la inconstitucional ampliación y modificación de su propia competencia en materia de control de constitucionalidad," en Libro Homenaje a Josefina Calcaño de Temeltas, Fundación de Estudios de Derecho Administrativo (FUNEDA), Caracas 2009, pp. 319362; Luis Alfonso Herrera Orellana, "El "recurso" de interpretación de la Constitución. Reflexiones críticas desde la argumentación jurídica y la teoría del discurso" en Revista de derecho público, №. 113, Editorial Jurídica Venezolana, Caracas, 2008, pp. 7-30. 
ámbito del Poder Ejecutivo sino también en el de los otros Poderes del Estado, ${ }^{17}$ en estas notas limitaremos nuestros comentarios, al aspecto medular del debate que nunca se dio, que es el relativo al control parlamentario de la Asamblea en relación con el Gobierno y la Administración Pública que conforman el Poder Ejecutivo Nacional, y sus propios actos.

Las normas cuya "interpretación" se solicitó fueron las que regulan las potestades de control político de la Asamblea Nacional, establecidas básicamente en los artículo 222 y 223 de la Constitución antes mencionados, cuyo contenido, por supuesto, nada tienen de ambiguo u oscuro, que pudiera ameritar "interpretación" alguna. Sin embargo, los "demandantes," respecto de la comparecencia de los Ministros ante la Asamblea Nacional para interpelaciones, investigaciones y preguntas conforme al artículo 222 y 223 , argumentaron que como los mismos deben presentar anualmente una "memoria razonada y suficiente sobre la gestión del despacho en el año inmediatamente anterior" (art. 244), la citación a comparecer ante la Asamblea les planteaba una supuesta "duda razonable" respecto a si, con ello:

"la Asamblea Nacional se estaría adelantando en solicitar la comparecencia de estos funcionarios, cuando la misma Constitución, en su artículo 244, establece el lapso para que dichas autoridades rindan la memoria razonada y suficiente sobre la gestión de su despacho del año inmediatamente anterior.

El otro aspecto relevante reposa en la incertidumbre que surge con relación a si, puede la Asamblea Nacional, con fundamento en las funciones de control y vigilancia establecidas en la Carta Fundamental, exigir la comparecencia de tales funcionarios para discutir el futuro económico del país y diseñar las políticas públicas y líneas de acción administrativa a ser desarrolladas por el Poder Ejecutivo, funciones estas últimas que el Texto Constitucional, en sus artículos 226, 238, 239 y 242,

$17 \quad$ Véase sobre el ámbito de la Administración Pública en la Constitución y en la Ley Orgánica de Administración Pública, lo expuesto en Allan R. Brewer-Carías, Introducción General al régimen jurídico de la Administración Pública" en Allan R. Brewer Carías et al, Ley Orgánica de la Administración Pública, $4^{\mathrm{a}}$ edición, Editorial Jurídica Venezolana, Caracas 2009, pp. 14-17. 
le otorga, de manera exclusiva y excluyente, al Poder Ejecutivo cuando le asigna competencia para dirigir la acción de gobierno."

Agregaron los demandantes en relación con los artículos 222 y 223 de la Constitución que además:

"surgen grandes incertidumbres respecto a si, puede la Asamblea, dentro de su función de control y vigilancia, convocar a los altos funcionarios a fin de "diagnosticar y diseñar políticas públicas"[...] cuando pareciera que el mecanismo constitucional que ejerce la Asamblea va dirigido a interpelar e investigar a los funcionarios públicos para la determinación de sus responsabilidades políticas por actuaciones concretas en su gestión administrativa."

Y todo ello considerando, supuestamente, que "las investigaciones desarrolladas por el Poder Legislativo, deben propender a la revisión de actuaciones materiales desarrolladas por el Ejecutivo y la determinación de responsabilidades, políticas, administrativas, patrimoniales," y supuestamente nada más.

Los "demandantes" exigieron de la Sala en esta materia una "decisión urgente" a los efectos de establecer y determinar "de manera clara y precisa, el contenido y alcance de la función de control y vigilancia ejercida por el Poder Legislativo sobre el Poder Ejecutivo Nacional."

A pesar de que la "demanda" de interpretación constitucional claramente incidía sobre los poderes constitucionales de la Asamblea Nacional, la cual, además, es la representación popular en la organización del Estado, como se dijo, la Sala Constitucional se dio el lujo de dictar sentencia violando abiertamente la garantía del debido proceso y el derecho a la defensa de la Asamblea, garantizado en el artículo 49 de la Constitución, contrariando su propia doctrina, que la considera como una "garantía suprema dentro de un Estado de Derecho;"18 que exige que "cualquiera sea la vía escogida para la defensa de los derechos

18 Véase sentencia No 123 de la Sala Constitucional (Caso: Sergio J. Meléndez) de 17 de marzo de 2000, en Revista de Derecho Público, No 81, (enero-marzo), Editorial Jurídica Venezolana, Caracas 2000, p. 143. 
o intereses legítimos, las leyes procesales deben garantizar la existencia de un procedimiento que asegure el derecho de defensa de la parte y la posibilidad de una tutela judicial efectiva," ${ }^{19}$ al punto de que ni siquiera puede ser desconocido por el legislador. ${ }^{20}$

Ello hace dicha sentencia nula, por inconstitucional. No es posible concebir que en un "proceso constitucional" se "juzgue" sobre las potestades de control político que corresponden constitucionalmente a la Asamblea Nacional, y se anulen actos dictados por la misma, incluso actos "futuros," sin que siquiera se haya citado a sus representantes a argumentar ante la Sala, y a defender sus decisiones.

Así como la propia Sala dijo en su sentencia que el Poder Legislativo Nacional "está sometido a la Constitución," también la Sala Constitucional a pesar de ser la máxime intérprete de la Constitución, está sometido a ella y no puede violarla impunemente, y si bien no hay mecanismo para controlarla, ello no excluye que el pueblo no tenga el derecho de desconocer sus decisiones como ilegítimas, conforme al artículo 350 de la propia Constitución.

\subsection{La potestad parlamentaria para controlar políticamente al Gobierno y a la Administración Pública y su regulación restrictiva por la Sala Constitucional}

La sentencia de la Sala Constitucional No 184 de 17 de marzo de 2016, en primer lugar, incidió directamente en el control político que conforme a los artículos 222 y 223 de la Constitución, le corresponde ejercer a la Asamblea Nacional sobre el Gobierno y la Administración Pública Nacional y, por tanto, sobre los funcionarios públicos de los mismos. El Gobierno conforme a la Constitución abarca a los niveles superiores del Poder Ejecutivo; y la Administración Pública, conforme a la propia Constitución abarca a todos

19 Véase sentencia No 97 de 15 de marzo de 2000 (Caso: Agropecuaria Los Tres Rebeldes), en Revista de Derecho Público, № 81, (enero-marzo), Editorial Jurídica Venezolana, Caracas 2000, p. 148.

20 Véase sentencia No 321 de 22 de febrero de 2002 (Caso: Papeles Nacionales Flamingo, C.A. vs. Dirección de Hacienda del Municipio Guacara del Estado Carabobo) en Revista de Derecho Público, No 89-92, (enero-diciembre) Editorial Jurídica Venezolana, Caracas 2002. 
los órganos del Estado que ejerzan la función administrativa y desarrollen funciones administrativas, cualquiera que sea la rama del Poder Público en la cual se encuentran. Por ello fue absolutamente errada la afirmación de la Sala Constitucional, en el sentido de que la Administración Pública solo está reducida al Poder Ejecutivo Nacional, cuando la Administración Pública del Poder Ciudadano, del Poder Electoral y del Poder Judicial (Dirección Ejecutiva de la Magistratura) son parte de la Administración Pública. ${ }^{21}$

Aparte de este grave error, en relación con el control parlamentario sobre los órganos del Poder Ejecutivo, la Sala destacó que una expresión principal de dicho control político-parlamentario en lo que se refiere al Jefe del Ejecutivo Nacional (artículo 226), cuando se le exige en el artículo 237 presentar cada año personalmente a la Asamblea Nacional un mensaje en el que debe dar cuenta de los aspectos políticos, económicos, sociales y administrativos de su gestión durante el año inmediatamente anterior; ámbito al cual, según la Sala Constitucional, "se ajusta ese control en lo que respecta al Jefe del Estado y del Ejecutivo Nacional." Agregó la Sala Constitucional, que respecto del Vicepresidente Ejecutivo (artículo 238) "ese control se expresa en la moción de censura al mismo, dentro del marco Constitucional” (artículo 240); y respecto de los Ministros, el control parlamentario encuentra expresión esencial en el artículo 244, cuando dispone que los mismos "presentarán ante la Asamblea Nacional, dentro de los primeros sesenta días de cada año, una memoria razonada y suficiente sobre la gestión del despacho en el año inmediatamente anterior, de conformidad con la ley;" disponiendo además, el artículo 246 que los Ministros pueden ser objeto de una moción de censura por parte de la Asamblea.

En esto, lo que hizo la Sala Constitucional fue simplemente glosar los artículos pertinentes de la Constitución, lo que en cambio no hizo al analizar los artículos 222 y 223 respecto del control político parlamentario en relación con los demás funcionarios del Poder Ejecutivo Nacional, "distintos al Presidente de

${ }_{21} \quad$ Véase sobre el ámbito de la Administración Pública en la Constitución y en la Ley Orgánica de Administración Pública, lo expuesto en Allan R. Brewer-Carías, Introducción General al régimen jurídico de la Administración Pública" en Allan R. Brewer Carías et al, Ley Orgánica de la Administración Pública, $4^{\mathrm{a}}$ edición, Editorial Jurídica Venezolana, Caracas 2009, pp. 14-17. 
la República, Vicepresidente Ejecutivo, y Ministros," procediendo sin ninguna fundamentación constitucional, a "legislar" en materia de control político parlamentario, supuestamente "para dar legitimidad y validez" a las actuaciones de la Asamblea, usurpando por supuesto su propia potestad normativa para ello, imponiéndole a la misma, como si fuera "legislador" por encima de la Asamblea, las siguientes normas o reglas de actuación, todas inconstitucionales por estar viciadas de usurpación de funciones normativas que solo corresponden a la Asamblea ejercer al dictar su reglamento interior y de debates:

Primera regla, que el control político que ejerza la Asamblea, lo debe ejercer:

"conforme a las demás reglas, valores y principios que subyacen al mismo, especialmente, el axioma de colaboración entre poderes, así como los de utilidad, necesidad y proporcionalidad, para que logre su cometido constitucional."

Segunda regla, que el control no debe afectar "el adecuado funcionamiento del Ejecutivo Nacional," y, en consecuencia, debe evitarse "que el mismo termine vulnerando los derechos fundamentales."

Tercera regla: que para realizar el control parlamentario, "debe observarse la debida coordinación de la Asamblea Nacional con el Vicepresidente Ejecutivo o Vicepresidenta Ejecutiva, tal como lo impone el artículo 239.5 Constitucional, para encausar la pretensión de ejercicio del referido control (canalización de comunicaciones, elaboración de cronograma de comparecencias, etc.), respecto de cualquier funcionario del Gobierno y la Administración Pública Nacional."

Cuarta regla, que dicha coordinación es a los efectos de que: "la Vicepresidencia Ejecutiva de la República centralice y coordine todo lo relacionado con las comunicaciones que emita la Asamblea Nacional con el objeto de desplegar la atribución contenida en el artículo 187.3 Constitucional, desarrolladas en los artículos 222 al 224 eiusdem."

Quinta regla, que la Asamblea Nacional al ejercer sus funciones de control, debe sopesar que:

"la insistencia de peticiones dirigidas hacia el Poder Ejecutivo Nacional e, inclusive, hacia el resto de poderes públicos, pudiera obstaculizar gravemente el funcionamiento del Estado, en detrimento de la garantía cabal de los derechos de las ciudadanas y ciudadanos, así como también de los derechos irrenunciables de la Nación." 
Sexta regla, que a tal efecto:

"las convocatorias que efectúe el Poder Legislativo Nacional, en ejercicio de las labores de control parlamentario previstas en los artículos $222 y$ 223, con el objeto de ceñirse a la juridicidad y evitar entorpecer el normal funcionamiento de los Poderes Públicos, deben estar sustentadas en todo caso en el orden constitucional y jurídico en general."

Séptima regla, que a tales efectos, las referidas convocatorias "deben estar dirigidas justamente a los funcionarios y demás personas sometidas a ese control," indicando:

(i) "La calificación y base jurídica que la sustenta;"

(ii) "el motivo y alcance preciso y racional de la misma;"

(iii) "orientarse por los principios de utilidad, necesidad, razonabilidad, proporcionalidad y colaboración entre poderes públicos;" y

(iv) "sin pretender subrogarse en el diseño e implementación de las políticas públicas inherentes al ámbito competencial del Poder Ejecutivo Nacional."

Octava regla: que en el control político parlamentario sobre los funcionarios, debe realizarse:

"permitiendo a los funcionarios que comparecen, solicitar y contestar, de ser posible, por escrito, las inquietudes que formule la Asamblea Nacional o sus comisiones."

Novena regla, que en esos casos, inclusive, debe garantizarse a los funcionarios:

"si así lo solicitaren, ser oídos en la plenaria de la Asamblea Nacional, en la oportunidad que ella disponga, para que el control en cuestión sea expresión de las mayorías y minorías a lo interno de ese órgano del Poder Público, las cuales han de representar a todas y todos los ciudadanos, y no únicamente a un solo sector."

Décima regla: que conforme al artículo 224 de la Constitución:

"el ejercicio de la facultad de investigación de la Asamblea Nacional no afecta [y, por ende, no ha de afectar] las atribuciones de los demás poderes públicos, pues obviamente la Constitución no avala el abuso ni la desviación de poder, sino que, por el contrario, plantea un uso racional y equilibrado del Poder Público, compatible con la autonomía de cada órgano del mismo, con la debida comprensión de la cardinal reserva de informaciones que pudieran afectar la estabilidad y la seguridad de la República, y, en fin, compatible con los fines del Estado." 
Décima primera regla: que respecto de la Fuerza Armada Nacional Bolivariana, el único control político parlamentario posible respecto de la misma es "a través de su Comandante en Jefe y del control parlamentario mediante el control político que se ejerce sobre su Comandante en Jefe $y$ autoridad jerárquica suprema" que es el Presidente de la República, solamente cuando presenta su mensaje anual ante la Asamblea para dar cuenta de los aspectos políticos, económicos, sociales y administrativos de su gestión durante el año inmediatamente anterior, a lo cual, dispuso la Sala, que "se limita el control previsto en el artículo 187.3 Constitucional -desarrollados en los artículos 222 y 223, en lo que respecta a dicha Fuerza." Por último, además, respecto de "las especificidades y a la forma en que deben desarrollarse las comparecencias ante la Asamblea Nacional, por parte del Ejecutivo Nacional y a la relación coordinada que debe existir entre ambas ramas del Poder Público," la Sala ordenó al Presidente de la República (al expresar que "tiene y debe") proceder a reglamentar la Ley sobre el Régimen para la Comparecencia de Funcionarios Públicos o los Particulares ante la Asamblea Nacional o sus Comisiones:

"con la finalidad de armonizar el normal desarrollo de las actuaciones enmarcadas en ese instrumento legal y demás ámbitos inherentes al mismo, siempre respetando su espíritu, propósito y razón."

Es decir, que incluso, el propio Poder Ejecutivo está obligado por la Sala Constitucional a limitar aún más las funciones de la Asamblea, al reglamentar dicha Ley.

Todo esto, por supuesto fue y es absolutamente inconstitucional, pues la Sala Constitucional no solo no es legislador, sino que no puede restringir ni regular las funciones de la Asamblea Nacional, que ejerce la representación popular; ni puede excluir de control político parlamentario sobre la Fuerza Armada Nacional, que es parte de la Administración Pública Nacional, y menos cuando a la misma se han asignado áreas de importancia de la actividad administrativa como han sido, por ejemplo, recientemente, los servicios de la industria petrolera y gas, con la creación de la Compañía Anónima Militar de Industrias Mineras, Petrolíferas y de Gas (CAMIMPEG), cuyas actividades ni siquiera tienen que ver con la administración de los asuntos militares. 
La secuela de todo ello, sin embargo, fue para la Sala Constitucional considerar y declarar, de oficio, mediante control difuso de constitucionalidad, la inconstitucionalidad de diversas normas del Reglamento Interior y de Debates de la Asamblea Nacional, y de la Ley sobre el Régimen para la Comparecencia de Funcionarios Públicos y los particulares ante la Asamblea Nacional, procediendo a abrir también de oficio, sendos procesos de nulidad por inconstitucionalidad de dichas normas.

\section{El fin del control político que debe ejercer la Asamblea Nacional: la inconstitucional "restricción" impuesta por el Presidente de la República, respecto de su potestad de aprobar votos de censura contra los ministros}

No contento con la aniquilación de la Asamblea Nacional por obra del Juez Constitucional, el Presidente de la República, también irrumpió contra la Constitución, y dio otro golpe de Estado contra la Asamblea Nacional, al dictar el Decreto No 2.309 de 2 de mayo de 2016, ${ }^{22}$ mediante el cual pretendió "restriñir y suspender" la potestad constitucional de la misma de aprobar votos de censura contra los Ministros, cuando lo juzgue políticamente oportuno y conveniente, a su exclusivo juicio.

Dicho acto presidencial también era absolutamente nulo e ineficaz, en los términos del artículo 138 de la Constitución, por estar viciado de usurpación de autoridad. Con este acto, después de que el Tribunal Supremo como antes hemos analizado, le negó a la Asamblea Nacional el poder ejercer autónomamente el control político en relación con las actuaciones del Gobierno y de la Administración Pública, entonces fue el Poder Ejecutivo Nacional el que directamente arremetió contra la Asamblea en forma totalmente inconstitucional.

$22 \quad$ Véase en Gaceta Oficial Extra. № 6225 de 2 de mayo de 2016. Véase los comentarios a dicho decreto en Allan R. Brewer-Carías, "La inconstitucional "restricción" impuesta por el Presidente de la República a la Asamblea Nacional para aprobar votos de censura contra los ministros." 8 de mayo de 2016, en http://www.allanbrewercarias.com/Content/449725d9f1cb-474b-8ab2-41 efb849fea3/Content/BREWER.\%20INCONSTITUCIONAL\%20 RESTRICCI\%C3\%93N\%20CENSURA\%20ASAMBLEA\%20A\%20MINISTROS\%20 8.5.2016.pdf 
En efecto, entre las competencias constitucionales de la Asamblea Nacional, que permiten considerar el sistema de gobierno en Venezuela contrariamente a lo afirmado por la Sala Constitucional, como un sistema presidencial "con sujeción parlamentaria," ${ }^{23}$ está la atribución establecida en el artículo 187.10 de la Constitución que le asigna el poder de:

"10. Dar voto de censura al Vicepresidente Ejecutivo o Vicepresidenta Ejecutiva y a los Ministros o Ministras. La moción de censura sólo podrá ser discutida dos días después de presentada a la Asamblea, la cual podrá decidir, por las tres quintas partes de los diputados o diputadas, que el voto de censura implica la destitución del Vicepresidente Ejecutivo o Vicepresidenta Ejecutiva o del Ministro o Ministra."

La consecuencia de la aprobación de un voto de censura a los altos funcionarios del Poder Ejecutivo, como manifestación del control político que a la Asamblea corresponde ejercer sobre los mismos, está establecida en la misma Constitución según que la censura se apruebe en relación con el Vicepresidente Ejecutivo o con los Ministros, en la siguiente

Artículo 240. La aprobación de una moción de censura al Vicepresidente Ejecutivo o Vicepresidenta Ejecutiva, por una votación no menor de las tres quintas partes de los integrantes de la Asamblea Nacional, implica su remoción. El funcionario removido o funcionaria removida no podrá optar al cargo de Vicepresidente Ejecutivo o Vicepresidenta Ejecutiva, o de Ministro o Ministra por el resto del período presidencial.

Artículo 246. La aprobación de una moción de censura a un Ministro o Ministra por una votación no menor de las tres quintas partes de los o

23 Contrariamente a lo que recientemente comienza a afirmar la Sala Constitucional, en el sentido de que Venezuela tendría un sistema "fundamentalmente presidencialista de gobierno" o un "sistema cardi-nalmente presidencial de gobierno." Véase la sentencia $\mathrm{N}^{\mathrm{o}} 269$ de 21 de abril de 2016, en http://historico.tsj.gob.ve/decisio-nes/scon/ abril/187363-269-21416-2016-11-0373.HTML Véase sobre el sistema de gobierno en Venezuela, Allan R. Brewer-Carías, "El sistema presidencial de gobierno en la Constitución de Venezuela de 1999," en el libro: Estudios sobre el Estado constitucional (2005-2006), Cuadernos de la Cátedra Fundacional Allan R. Brewer Carías de Derecho Público, Universidad Católica del Táchira, № 9, Editorial Jurídica Venezolana, Caracas, 2007, pp. 475-624 
las integrantes presentes de la Asamblea Nacional, implica su remoción. El funcionario removido o funcionaria removida no podrá optar al cargo de Ministro o Ministra, ni de Vicepresidente Ejecutivo o Vicepresidenta Ejecutiva por el resto del período presidencial.

Y más nada dispone la Constitución. Estas son las normas que regulan esta competencia que es esencialmente de carácter político para ser ejercida por un órgano que es esencialmente político, y que pone en funcionamiento el ejercicio de un control político por parte de la mayoría que controla políticamente a la Asamblea Nacional en relación con la ejecución de las políticas públicas por parte del Poder Ejecutivo.

En uso de estas atribuciones, la Asamblea Nacional, luego de los debates correspondientes, aprobó un Acuerdo ${ }^{24}$ mediante el cual dio un Voto de Censura al Ministro para la Alimentación, Marco Torres, por su incomparecencia ante la Asamblea para ser interpelado y oído, lo "que fue considerado por el órgano legislativo como una renuencia del Gobierno a explicar la situación de escasez de alimentos en el país." Como lo explicó el Presidente de la Asamblea Nacional: "hubiese sido preferido escuchar al ministro Marco Torres, quien había sido citado por la Cámara para que viniera a la sesión de este jueves, pero tampoco se presentó." Luego de explicar que la invitación al funcionario le fue enviada también al vicepresidente de la República, Aristóbulo Istúriz, dijo: "Hemos cumplido estrictamente con el dispositivo constitucional; hubiésemos querido escuchar la exposición del ministro Marco Torres sobre la crisis alimentaria."25

La reacción del gobierno fue inmediata en contra de la Asamblea Nacional. El mismo día 28 de abril, el Presidente de la República expresó desconociendo la Constitución, que "al ministro de Alimentación no lo remueve nadie," ${ }^{26}$

$24 \quad$ Véase "Asamblea aprueba voto de censura al ministro de Alimentación Marco Torres," en El Universal, 28 de abril de 2016, en http:/www.eluni-versal.com/noticias/politica/ asamblea-aprueba-voto-censura-ministro-alimentacion-marco-torres_307078 Véase igualmente en: http://m.pano-rama.com.ve/politicayeconomia/AN-debate-voto-decensura-a-ministro-de-Alimentacion-Rodolfo-Marco-Torres-20160428-0027.html

25 Idem.

26 Véase en http://www.eluniversal.com/noticias/politica/maduro-rechaza-voto-censuraministro-alimentacion-marco-torres_307192. 
rechazando el Voto de Censura contra el mismo, ${ }^{27}$ expresando entre otras cosas que:

"Esa decisión es írrita y nula, y como írrita y nula no existe, así de sencillo. Le digo al señor Ramos Allup, al ministro no lo remueve nadie. Acate la sentencia del TSJ," agregando además que:

"La Asamblea Nacional debe acatar en todas sus partes, la sentencia del TSJ y sencillamente ellos han declarado abiertamente que no la van a acatar, y estamos en el marco de una emergencia económica, esos artículos de la Constitución, vamos a revisar para sacar un decreto en el marco del decreto vigente, constitucional, que emití desde el mes de enero, para dejar sin efecto constitucionalmente mientras dure la emergencia económica, cualquier sabotaje que haga la Asamblea Nacional contra cualquier ministro, institución u órgano del poder popular, vamos a sacar un decreto especial de emergencia, mañana mismo."28

Estas primeras apreciaciones sobre la supuesta incompatibilidad del ejercicio del control político por parte de la Asamblea Nacional, el supuesto "desacato" por la misma de la sentencia de la Sala Constitucional que había restringido" la forma de citar a los Ministros para interpelarlos, ${ }^{29}$ fueron complementadas por el propio Presidente de la República al día siguiente 29 de abril, en particular en cuanto a su determinación de proceder a "revisar" [¿reformar? ¿reformular? ¿modificar?] los artículos de la Constitución y mediante decreto ejecutivo dejar "sin efecto las potestades constitucionales de la Asamblea Nacional. ${ }^{30}$ Anunció, en efecto el Presidente de la República, que:

"promulgará un decreto para "dejar sin efecto" cualquier "sabotaje" que realice el Parlamento contra "cualquier ministro u órgano del poder popular" en referencia a la moción de censura aprobada contra el ministro de Alimentación.

\footnotetext{
${ }_{27} \quad$ Véase en http://notiexpresscolor.com/maduro-ministro-no-lo-remueve-nadie/.

28 Idem.

29 Idem

30 Véase: "Maduro promulgará decreto para "dejar sin efecto" decisiones del Parlamento," en Diario Las Américas, 29 de abril de 2016, en http://www.diariolasame-ricas. com/4848_venezuela/3782331_maduro-promulgara-decreto-dejar-efecto-decisiones-delparlamento.html.
} 
"Esos artículos de la Constitución vamos a revisarlos para sacar un decreto para dejar sin efecto constitucionalmente, mientras dure la emergencia económica, cualquier sabotaje que haga la Asamblea contra cualquier ministro, institución u órgano del poder popular," dijo Maduro en un acto desde la Refinería de Puerto La Cruz, estado Anzoátegui. "Mañana mismo vamos a sacarlo porque no nos podemos calar un sabotaje." 31

Y efectivamente en la prensa del 4 de mayo se reseñó en los medios de comunicación que el Presidente de la República había distado un decreto que "resta poderes a la Asamblea Nacional de Venezuela," ${ }^{32}$ es decir, para:

"restringir y diferir las mociones de censura que se hagan desde el Parlamento de mayoría opositora contra sus ministros que tienen como consecuencia la remoción del cargo de los funcionarios, según la Constitución.”

En el decreto hecho público se indica que esta decisión del Gobierno tendrá validez "hasta tanto cesen los efectos del Decreto de Emergencia Económica dictado por el presidente" con el objetivo de "garantizar la continuidad en la ejecución de las medidas económicas de emergencia." 33

La decisión del Poder Ejecutivo se conoció el 5 de mayo de 2016, cuando apareció en Gaceta Oficial Extraordinaria No 6225 del 2 de mayo de 2016, el Decreto No 2309 de 2 de mayo de 2016, ${ }^{34}$ en el cual el ejercicio de esta potestad constitucional de control político atribuida al órgano que ejerce la representación popular de poder declarar Voto de censura a los Ministros, simple e insólitamente fue "restringida y suspendida" por el Jefe del Poder Ejecutivo, que es el órgano controlado, es decir, por el Presidente de la República cuyos subalternos (Vicepresidente Ejecutivo y Ministros son los controlados y controlables por la Asamblea) violando descaradamente la Constitución y el principio de la

\footnotetext{
$31 \quad$ Idem.

32 Véase "Decreto de Maduro resta poderes a la Asamblea Nacional de Venezuela," 4 de mayo de 2016, en http://noticias.terra.com/decreto-de-maduro-resta-poderes-a-laasamblea-nacional-de-venezuela,b9ab08070bf18b140ca4e473ca4bbbaekpx40avv.html.

33 Idem.

34 Véase en Gaceta Oficial Extraordinaria No 6225 de 2 de mayo de 2016.
} 
separación de poderes que impone la autonomía e independencia de los Poderes Públicos que garantiza su artículo $136,{ }^{35}$ por supuesto, sin que el Presidente de la República tuviera competencia constitucional ni legal alguna para ello.

\subsection{Un decreto ineficaz y nulo por estar viciado de incompetencia manifiesta por usurpación de autoridad y usurpación de funciones}

El decreto No 2309 de 2 de mayo de 2016, en efecto, debe señalarse que de entrada fue dictado en violación de los artículos $137^{36}$ y 236.24 de la Constitución. El primero dispone que la "Constitución y la ley definen las atribuciones de los órganos que ejercen el Poder Público, a las cuales deben sujetarse las actividades que realicen,"; y el segundo dispone que el Presidente de la República solo puede ejercer las competencias "que le señalen esta Constitución y la ley."

Basta leer la Constitución para constatar que ninguna norma constitucional autoriza al Presidente de la República para en forma alguna "restringir" las potestades constitucionales de la Asamblea Nacional y menos "suspenderlas." Por ello, como se dijo, el decreto, de entrada, es totalmente ineficaz y nulo por estar viciado de usurpación de autoridad conforme a lo establecido en el artículo 138 de la Constitución. Como lo ha observado José Ignacio Hernández al argumentar sobre las razones por las cuales el Presidente de la República no podía dictar el Decreto mencionado:

"La primera razón es muy obvia: el Presidente no puede, ni siquiera en un estado de excepción, restringir y diferir la aplicación de la Constitución. Así lo dispone el Artículo 7 de esa Constitución: los Poderes Públicos se someten a la Constitución, pero no lo contrario, que es lo que pretende el Decreto.

$35 \quad$ Artículo 136. El Poder Público se distribuye entre el Poder Municipal, el Poder Estadal y el Poder Nacional. El Poder Público Nacional se divide en Legislativo, Ejecutivo, Judicial, Ciudadano y Electoral. / Cada una de las ramas del Poder Público tiene sus funciones propias, pero los órganos a los que incumbe su ejercicio colaborarán entre sí en la realización de los fines del Estado.

36 Artículo 137. "Esta Constitución y la ley definen las atribuciones de los órganos que ejercen el Poder Público, a las cuales deben sujetarse las actividades que realicen.” 
La segunda razón es que el Presidente de la República no puede prohibirle a la Asamblea Nacional el ejercicio de una competencia propia del Poder Legislativo. Para eso existe el principio de separación de poderes, que es una garantía básica de la libertad para prevenir el abuso de poder y el despotismo.

Por último, el Poder Ejecutivo no puede impedir que la Asamblea Nacional lo controle, incluso, acordando votos de censura. El sujeto controlado no puede limitar la conducta del sujeto que controla." ${ }^{37}$

El vicio de incompetencia manifiesta del Decreto, además, se evidenció de su propio texto, en particular de la supuesta "base legal" que se buscó para "fundamentarlo," es decir, las normas que se citaron en su propio texto y en cuyo supuesto ejercicio se dictó, que fueron por lo que respecta a normas

$37 \quad$ Véase José Ignacio Hernández, “¿Ahora la AN no podrá dictar votos de censura?, en Prodavinci, 4 de mayo de 2016, en http://proda-vinci.com/blogs/ahora-la-an-nopodra-dictar-votos-de-censura-por-jose-ignacio-hernandez-g/ En el mismo sentido la Organización Acceso a la Justicia explicó que "el decreto presidencial persigue prohibir el ejercicio legítimo de las competencias de la Asamblea Nacional previstas en la Carta Fundamental del país, con la excusa de la vigencia del estado de emergencia económica. / Es importante señalar que un estado de excepción no significa que el Presidente de la República pueda suspender las normas del texto constitucional y socavar los cimientos del Estado de derecho y democrático, y más aún cuando dicha emergencia económica (declarada en todo el territorio nacional) y su prórroga fueron dictadas sin cumplir con las exigencias para su procedencia, como ya fue advertido por Acceso a la justicia. / Por otro lado, interesa dejar claro que la declaratoria del estado de excepción no es aval para cometer arbitrariedades y actuar por encima de los preceptos de la Constitución, en este caso, interfiriendo de manera caprichosa en las competencias del Poder Legislativo, especialmente para impedir que dicte votos de censura contra los funcionarios que están sujetos a su control parlamentario, y de esta manera crear una inmunidad política al Vicepresidente Ejecutivo y a los ministros." Véase "El Presidente prohíbe que la AN dicte votos de censura: "Algo huele mal en Dinamarca," en Acceso a la Justicia, Observatorio Venezolano de la Justicia, 10 de mayo de 2016, en http://www.accesoalajus-ticia.org/wp/ infojus-ticia/noticias/el-presidente-prohibe-que-la-an-dicte-votos-de-censura-algo-huelemal-en-dinamar. 
constitucionales, los numerales $3,^{38} 7,{ }^{39} 16^{40}$ y $20^{41}$ del artículo 236 de la Constitución que enumera las atribuciones del Presidente. Todo ello fue por supuesto descaradamente falso, pues ninguna de esas normas (basta leer su texto) asignan competencia alguna al Presidente de la República como Jefe del Poder Ejecutivo, para restringir o suspender las atribuciones constitucionales de la Asamblea Nacional.

La otra norma legal en la cual supuestamente se basó el Presidente para dictar el Decreto restringiendo y suspendiendo las atribuciones constitucionales de la Asamblea es el artículo 15 de la Ley Orgánica sobre los Estados de Excepción, en la cual se dispone que:

“Artículo 15. El Presidente de la República, en Consejo de Ministros, tendrá las siguientes facultades: a) Dictar todas las medidas que estime convenientes en aquellas circunstancias que afecten gravemente la seguridad de la Nación, de sus ciudadanos y ciudadanas o de sus instituciones, de conformidad con los artículos 337, 338 y 339 de la Constitución de la República Bolivariana de Venezuela. b) Dictar medidas de orden social, económico, político o ecológico cuando resulten insuficientes las facultades de las cuales disponen ordinariamente los órganos del Poder Público para hacer frente a tales hechos.”

Dichas competencias solo pueden ejercerse dentro del marco de las atribuciones constitucionales, sin que esta norma legal pueda considerarse como una carta en blanco para violar la Constitución.

38 Artículo 236.3: "Nombrar y remover al Vicepresidente Ejecutivo o Vicepresidenta Ejecutiva, nombrar y remover los Ministros o Ministras."

39 Artículo 236.7: "Declarar los estados de excepción y decretar la restricción de garantías en los casos previstos en esta Constitución."

40 Artículo 236.16: "Nombrar y remover a aquellos funcionarios o aquellas funcionarias cuya designación le atribuyen esta Constitución y la ley."

$41 \quad$ Artículo 236.20: "Fijar el número, organización y competencia de los ministerios y otros organismos de la Administración Pública Nacional, así como también la organización y funcionamiento del Consejo de Ministros, dentro de los principios y lineamientos señalados por la correspondiente ley orgánica." 


\subsection{Un decreto nulo por invadir $y$ afectar el ejercicio por la Asamblea Nacional de sus facultades constitucionales}

De acuerdo con el artículo 339 de la Constitución, la declaración del estado de excepción por parte del Presidente de la República "no interrumpe el funcionamiento de los órganos del Poder Público," de manera que más clara no pudo haber sido la intención del Constituyente al regularlos, lo que implica que en ningún caso esa declaratoria podría interrumpir el cumplimiento de la función esencial de la Asamblea Nacional para legislar y de controlar la acción política del gobierno y la actividad de la Administración Pública conforme se indica en el artículo 187 de la misma Constitución.

Por tanto, por más que el Presidente de la República haya dictado el Decreto $\mathrm{N}^{\circ} 2.184$ de fecha 14 de enero de 2016, mediante el cual declaró el Estado de Emergencia Económica en todo el Territorio Nacional, el cual fue prorrogado mediante Decreto $\mathrm{N}^{\circ} 2.270$ de fecha 11 de marzo de 2016, ello en ninguna forma pudo interrumpir el funcionamiento de la Asamblea Nacional.

En consecuencia, un decreto ejecutivo como el dictado con el № 2039 de 2 de mayo de 2016, aparte de sus vicios de incompetencia manifiesta que lo afectan, es esencialmente inconstitucional al pretender, como lo dijo su propio texto, restringir y diferir el ejercicio de sus funciones por parte de la Asamblea Nacional.

En efecto, el artículo 1 del decreto dispuso:

Artículo $1^{\circ}$. Se restringe y difiere de acuerdo al artículo $N^{\circ} 236$ numeral 7 , de la Constitución de la República Bolivariana de Venezuela, las mociones de censura que pudiera acordar la Asamblea Nacional contra los Ministros y Ministras del Poder Popular, o contra el Vicepresidente Ejecutivo, en las cuales solicitaren su remoción, hasta tanto cesen los efectos del Decreto de Emergencia Económica dictado por el Presidente de la República en Consejo de Ministros; ello a fin de garantizar la continuidad en la ejecución de las medidas económicas de emergencia encomendadas al Gabinete Ejecutivo y de las cuales depende la estabilización de la economía 
nacional y la satisfacción oportuna y continua de las necesidades de los venezolanos y venezolanas en el orden económico."

O sea, de entrada, atropellando lo establecido en el citado ar-tículo 339 de la Constitución conforme al cual el decreto de estado de excepción "no interrumpe el funcionamiento de los órganos del Poder Público," el Decreto precisamente buscó todo lo contrario para lo cual se basó precisamente en el artículo 267.7 constitucional que es el que solo atribuye al Presidente el poder de decretar dichos Estados de excepción.

Es decir, no puede un decreto de estado de excepción, interrumpir el funcionamiento de la Asamblea al "restringir y diferir" el ejercicio de su competencia para poder aprobar las mociones de censura que estime políticamente oportunas y convenientes contra los Ministros y el Vicepresidente Ejecutivo y solicitar incluso "su remoción." Sin embargo, al contrario, el Presidente procedió a dictar esa "restricción y suspensión" a la Asamblea, "hasta tanto cesen los efectos del Decreto de Emergencia Económica," a los efectos de supuestamente "garantizar la continuidad en la ejecución de las medidas económicas de emergencia," las que por lo visto sólo podían ejecutarse por personas individualizadas y no por funcionarios que ejercer un cargo.

Esta barbaridad jurídica fue dictada con base en un conjunto de motivaciones que se consignaron en los "considerandos" del Decreto, que dejando aparte muchos lugares comunes floridos - lo que sirvieron fue para evidenciar el atropello cometido.

Lo primero que llama la atención es que el Presidente consideró que su propio Decreto de Estado de Emergencia Económica, supuestamente le daba "Poderes Especiales para defender y preservar la paz, la estabilidad y el derecho al desarrollo independiente de Nuestra Patria," cuando ello no era cierto pues ese objetivo lo tenían que perseguir todos los órganos del Estado, de manera que lo que le permitió el mencionado Decreto es solo lo que en él se estableció y no era una carta blanca para atropellar a los demás Poderes Públicos.

Sin embargo, refiriéndonos ahora a las "motivaciones" sustantivas del decreto de aniquilación de la función política de la Asamblea Nacional de 
controlar el Gobierno y la Administración Pública, el segundo Considerando era explícito, al considerar - dejando de lado el sin sentido de que el Presidente calificara a la mayoría de la oposición en la Asamblea resultante de la abrumadora elección del 6 de diciembre de 2015, como "una mayoría burguesa circunstancial," que actuaba en "acatamiento de órdenes de gobiernos extranjeros" por el hecho de que la Asamblea hubiera comenzado a ejercer sus funciones sin sujeción al Ejecutivo como ocurrió hasta diciembre de 2015; entonces considerase que ello era actuar en forma "opuesta al orden constitucional [...], apartándose con su acción de la naturaleza legisladora de dicho órgano legislativo, dedicándose al plano de la confrontación política." Es decir, para el Presidente de la República, todo acto legislativo motivado por el ejercicio de una oposición al gobierno, era "inconstitucional," catalogándose a la oposición en definitiva como un "enemigo interno" que había que enfrentar con normas "no convencionales."

Luego pasó el Presidente en el Decreto a considerar lo que podría ser la motivación central del Decreto, que no fue otra que si el Presidente tenía la competencia para nombrar sus Ministros, entonces nadie podría removerlos, ni siquiera cuando ello estuviese así previsto en la Constitución; reclamando para sí "la garantía de autonomía en cuanto a la designación" de su equipo de gobierno, que nadie le había negado, pero desconociendo el ejercicio autónomo de las potestades de los otros órganos del Poder Público.

Con base en ello, consideró en forma absurda que el ejercicio por parte de la Asamblea Nacional de su potestad de aprobar una moción de censura a un Ministro, y removerlo a consecuencia de ello, atentaría "contra la continuidad de la ejecución de políticas públicas, acarreando una mora en las actividades de la Administración Pública." Consideró, además el Presidente que la Administración Pública no puede "ser sometida a constantes perturbaciones y amenazas por parte de cualquier instancia del Poder Público," ignorando por supuesto el texto mismo de la Constitución, estimado los actos de la Asamblea como de "aparente institucionalidad," pero acusándola de pretender "subrogarse en funciones de otros Poderes, intentando ejercer la gestión de asuntos públicos que corresponden al Ejecutivo Nacional," pero sin decir, por supuesto, cuáles. 
Luego el Presidente, en los Considerandos del Decreto, pasó a acusar a la Asamblea de supuestamente ejercer competencias no previstas en la Constitución, - sin decir por supuesto cuáles - indicando como si él mismo fuera "el pueblo" que:

"cada una de las actuaciones que ha realizado desde su instalación y hasta la fecha, están claramente dirigidas a tomar el control absoluto, autoritario y despótico del poder que sólo el Pueblo detenta, apuntando para ello a la destrucción del Estado Venezolano."

Acusación ésta gravísima entre órganos del Estado; gravísima; formulada en general e irresponsablemente, sin mencionar hecho alguno que pudiera justificar tal aserto. En realidad lo único que mencionó el Presidente sobre esto, fue que la Asamblea Nacional, en uso de sus atribuciones constitucionales de control político, había aprobado una Moción de Censura contra el ciudadano Rodolfo Clemente Marco Torres, en su carácter de Ministro del Poder Popular para la Alimentación destacando que ello fue "con una indudable motivación política" u "obedeciendo a conveniencias políticas"” - como si ello fuera un fraude, cuando una mención de censura no puede tener otra motivación que no sea política - que es la única que puede tener; alegando que la Asamblea Nacional quería imponer un "modelo económico rechazado por el pueblo hace más de 17 años," cuando ello no es cierto y basta leer la Constitución de 1999. En realidad lo que en materia de modelos económicos el pueblo sí rechazó en 2007, fue el modelo presentado en la reforma constitucional propuesta por Chávez para la implementación de un Estado socialista, que sin embargo, en fraude a la voluntad popular, es el que ha sido aplicado y desarrollado por el Gobierno. ${ }^{42}$

En todo caso, el Presidente no era quién para juzgar si la aprobación de un voto de censura era o no justificada, como resultó de su afirmación en los Considerandos del decreto de que existía "fundado convencimiento en torno a

$42 \quad$ Véase Allan R. Brewer-Carías, La Reforma Constitucional de 2007 (Comentarios al Proyecto Inconstitucionalmente sancionado por la Asamblea Nacional el 2 de noviembre de 2007), Colección textos legislativos $\mathrm{N}^{\circ}$ 43, Editorial Jurídica Venezolana. Caracas, 2007, 224 pp.; y "La reforma constitucional en Venezuela de 2007 y su rechazo por el poder constituyente originario," en José Ma. Serna de la Garza (Coordinador), Procesos Constituyentes contemporáneos en América latina. Tendencias y perspectivas, Universidad Nacional Autónoma de México, México 2009, pp. 407-449. 
la aplicación justificada de la moción de censura a los miembros del Gabinete Ejecutivo por parte de la Asamblea Nacional.” El Presidente no tenía por qué presumir que todo voto de censura es una "vía de ejercicio político tendente a socavar la acción de Gobierno, hacer daño a la economía de la República y desestabilizar la sociedad venezolana, poniendo en riesgo la paz nacional," o que con ello se pretendía realizar un "sabotaje inescrupuloso" para afectar "la organicidad del Poder Ejecutivo.”

Con su decreto usurpador, en realidad, fue el Presidente de la República, no la Asamblea Nacional, el que buscó agravar "un conflicto de poderes, una confrontación para la inestabilidad de las instituciones republicanas, que en nada favorece a la situación que en los actuales momentos vive Venezuela," como lo expresó en el último de los considerandos de su decreto.

\subsection{La restricción por parte del Poder Ejecutivo de las competencias constitucionales de la Asamblea Nacional}

Con base en las motivaciones anteriores, el Presidente de la República procedió entonces a restringir en el marco del decreto sobre emergencia económica, sin tener competencia constitucional ni legal alguna para ello, las competencias constitucionales de la Asamblea Nacional en la siguiente forma:

En primer lugar, refiriéndose a su competencia para decretar estados de excepción (artículo 236.7, Constitución), decretó no sólo la restricción sino el diferimiento ("se restringe y difiere") "de las mociones de censura que pudiera acordar la Asamblea Nacional" contra los Ministros y el Vicepresidente Ejecutivo, "en las cuales solicitaren su remoción [...] hasta tanto cesen los efectos del Decreto de Emergencia Económica dictado por el Presidente de la República en Consejo de Ministros," todo con el objeto de "garantizar la continuidad en la ejecución de las medidas económicas de emergencia encomendadas al Gabinete Ejecutivo."

Ignoró el Presidente que el funcionamiento de la Administración Pública y la continuidad de la ejecución de las políticas públicas no depende de alguna persona en particular, como la que en un momento determinado pueda ejercer el cargo de Ministro, sino de la organización de la propia Administración 
Pública que tiene que funcionar, sea quien fuere el Ministro de turno. Por tanto, la moción de censura y remoción de un Ministro no puede por principio alterar la continuidad de la Administración, no teniendo por tanto justificación alguna el inconstitucional decreto.

En segundo lugar, el Presidente instruyó a la Procuraduría General de la República para que, en el marco de sus competencias, "realice los análisis jurídico constitucionales pertinentes $\mathrm{y}$, de lucir procedente, interponga el correspondiente Recurso por Controversia Constitucional entre órganos del Poder Público ante la Sala Constitucional del Tribunal Supremo de Justicia, de conformidad con el artículo 336, numeral 9, de la Constitución de la República Bolivariana de Venezuela, a fin de procurar el mantenimiento de los equilibrios de los poderes y la gobernabilidad."

Si ese recurso llegara a interponerse, y si en Venezuela existiese una Sala Constitucional autónoma e independiente, sin duda que lo que resultaría sería declararlo improcedente, por impertinente, porque no puede haber "controversia constitucional" alguna entre la Asamblea Nacional y el Ejecutivo Nacional, como consecuencia de que la primera dé un voto de censura a algún Ministro en ejercicio del control político que le corresponde realizar conforme a la Constitución.

En todo caso, es difícil encontrar un ejemplo de acto estatal dictado con tanto abuso de poder, tanta arbitrariedad y tanto desconocimiento constitucional como este de la restricción por parte del Poder Ejecutivo de las competencias constitucionales de la Asamblea Nacional, que si hubiese un Juez Constitucional autónomo e independiente, no dudaría en anularlo in limine.

New York, junio 2016 